\title{
Crônica de uma morte anunciada: do suicídio entre os Sorowaha ${ }^{1}$
}

\author{
João Dal Poz \\ Professor do Departamento de Ciências Sociais - UFMT \\ O suicídio é uma solução para o absurdo.
}

(Albert Camus)

\begin{abstract}
RESUMO: A prática de suicídio nos Sorowaha, povo de língua Arawa do médio Purus (AM, Brasil), através da ingestão do sumo da raiz de timbó (konaha), mediatiza singularmente as relações entre os indivíduos e a sociedade, projetando uma totalidade social às expensas de um drama ritual individualizador. A relevância do fenômeno é evidenciada tanto pelas taxas de mortalidade que ali se verificam, cerca de cem vezes as médias ocidentais, como também pela inusitada freqüência com que as tentativas, por motivos os mais variados, ocorrem entre eles. O presente ensaio procura examinar as variáveis sociológicas desse padrão de morte voluntária, para em seguida discutir outras dimensões analíticas.
\end{abstract}

PALAVRAS-CHAVE: Sorowaha, Arawa, etnologia sul-americana, morte, suicídio, indivíduo.

As implicações sociológicas da morte voluntária entre os Sorowaha, e seu repertório de motivos, condutas e relações aqui expostos de forma abreviada $^{2}$, não apenas autorizam, de um ângulo bastante singular, uma revisão do conhecido esquema durkheimiano, mas podem também sugerir novas dimensões analíticas a uma etnologia ameríndia. Diante de um comportamento suicidógeno tão generalizado, à investigação etnológica 
cumpre apreendê-lo enquanto uma afirmação eloqüente e talvez irredutível, um evento basilar que articula o socius de maneira inesperada. Tal deslocamento metodológico, ao buscar hereticamente uma positividade num ato tão extremado, vai de encontro a alguns dos pressupostos das abordagens clássicas, visto que a totalização sociológica e a individuação psicológica ali não perceberam mais que instabilidade, descontrole, deserção, fraqueza ou insanidade.

O problema, decerto, requer um esforço semelhante ao que, décadas atrás, facultou libertar do ostracismo intelectual e da paralisia teórica a reflexão sobre a morte (Morin, 1990). Trata-se, do meu ponto de vista, de considerar o suicídio pelo que enseja, de verificar em que medida este tipo de auto-agressão representaria um mecanismo capaz de conformar, de um modo ou outro, processos sociais mais abrangentes. Se é verdade, como dele disse Camus, que o suicídio é uma tentativa de dispor "uma solução para o absurdo", é preciso também admitir que este dilema não lhe cabe como atributo privativo, posto que atravessa as muitas e variadas fórmulas sociológicas que geometrizam significados particulares à existência humana. Se se deve distingui-la, deve-se antes ao efeito paradoxal de uma sociabilidade que se constrói às expensas de um rito francamente individualizador, o gesto suicida ${ }^{3}$.

Os Sorowaha falam uma língua da família Arawa e habitam as terras altas entre os igarapés Riozinho e Coxodoá, afluentes da margem direita do Cuniuá - com seu curso em direção a leste, este último é um dos formadores do rio Tapauá, importante tributário da margem esquerda da bacia do Purus (Amazonas, Brasil). Afastados das principais vias de navegação, os Sorowaha mantiveram seu cauteloso isolamento até fins da década de 70, quando foram localizados por missionários da Prelazia de Lábrea, alertados de sua existência pelas notícias de conflitos com sorveiros que invadiram o território indígena. A partir de 1984, a equipe do chamado Projeto Zuruaha ${ }^{4}$, em visitas mais regulares, deparou-se com freqüentes tentativas de suicídio e soube, então, de vários casos fatais recentes (Kroemer, 1989). 
Ponto cego na etnologia sul-americana, ou porque aí se divisava uma certa negação da condição "primitiva", ou então a resultante de processos de desintegração social, esse tema contabilizou pouquíssimos registros até o momento ${ }^{5}$. Mais um ardil forjado pela noção de "primitividade" na seara antropológica? Há motivos de sobra para suspeitas. Por um lado, aqui e alhures a guerra e os ritos sacrificiais - melhor dizendo, as modalidades de violência contra Outros - enriqueceram um sem número de inventários etnográficos; por outro, inversamente, a despeito da enorme relevância teórica confiada ao estudo clássico de Durkheim, os fatos relativos à morte voluntária nas sociedades "elementares", com raras exceções (Bohannan, 1960; Firth, 1967; e algumas pesquisas melanésias mais recentes), estão ainda relegados a um desdém indulgente ${ }^{6}$.

No Brasil a questão veio à baila nos últimos anos, depois que jornais e tevês deram destaque à "epidemia" que vitimava os Guarani. Constrangimentos políticos e morais à parte, o fenômeno suscitou até agora uma plêiade de debates e algumas interpretações preliminares (Azevedo, 1991; Bom Meihy, 1994; Brand, 1995; Levcovitz, 1998). Ao lado destes e de outros estudos, a análise criteriosa do caso sorowaha, sem dúvida um exemplo etnográfico invulgar, talvez venha a contribuir para uma reconsideração da morte voluntária enquanto fato social. Deixo portanto de lado, no âmbito deste ensaio, possíveis comparações com outras tantas condutas radicais observadas nas sociedades humanas, para melhor situar os dados Arawa em face das teorias sobre o suicídio e das controvérsias atuais da etnologia sul-americana.

\section{Apontamentos etnográficos}

Em janeiro de 1996, os Sorowaha ${ }^{7}$ somavam 144 pessoas. Não obstante recuos em determinados anos, sua população vem crescendo em ritmo lento desde 1980, quando eram pouco mais de cem. Contam eles, e disto temos outras evidências históricas (Barros, 1930), que são remanescentes de uns tantos subgrupos territoriais nominados ${ }^{8}$ cujos contingentes, sucum- 
bindo às doenças infecto-contagiosas e à impiedade da economia da borracha, decresceram drasticamente nas primeiras décadas do século $\mathrm{XX}$, no período de maior expansão das atividades extrativistas em toda a Amazônia. Alguns subgrupos, entre eles os Masanidawa, que então moravam próximos da foz do igarapé Riozinho, e os antigos Sorowaha (ver abaixo), às margens do Cuniuá, chegaram a entabular relações amistosas com os seringueiros (os Jara, como são chamados os civilizados), e assim obtiveram roupas e ferramentas - machados, facões, anzóis e cordas que logo se tornaram objetos de troca com os demais subgrupos (Fank \& Porta, 1996 b: 24, 42-43, 242). Porém, dizimados pela gripe (o auxiliar do SPI José Sant'Anna de Barros notificou epidemias na bacia do Tapauá entre os anos de 1922 e 1924, com grande mortandade entre a população indígena, cf. Barros, 1930: 11) e receosos de novos ataques dos Abamady (provavelmente os Paumari do baixo Tapauá, armados com espingardas fornecidas pelos seringalistas, cf. Kroemer, 1994: 129; Fank \& Porta 1996 b: 72-3), uns poucos sobreviventes de diferentes subgrupos buscaram refúgio nas redondezas do igarapé Jokihi (ou Pretão, para os regionais), o mais distante possível das rotas fluviais e das "colocações" dos adventícios, onde se reuniram aos Jokihidawa (literalmente, "o pessoal do Jokihi”), o subgrupo que ali residia originalmente.

Subgrupos nominados foram já observados em outros povos de língua Arawa - assim, os madiha nos Kulina (Pollock, 1985; 1992), os deni nos Jamamadi (Rangel, 1994) e os deni nos Deni (Koop \& Lingenfelter, 1980). Embora persistam dúvidas quanto a regras de pertencimento e outros aspectos gerais, as descrições etnográficas mencionam, unânimes, a existência de múltiplas unidades locais, sujeitas a sucessivas fissões e migrações em razão de conflitos internos ou com grupos análogos e com estrangeiros. Neste quadro, a violência e as acusações de feitiçaria expressariam, ao mesmo tempo, as desconfianças mútuas, as trocas fracassadas e a atribuição de culpa em situações de doença ou óbito.

Para os Sorowaha, unidades desse tipo são designadas pelos seguintes termos: - dawa, num sentido quase restrito aos seus próprios subgrupos; 
Revista de Antropologia, São Paulo, USP, 2000, v. 43 nº 1.

e mady, cuja semântica é, conforme o contexto, mais ou menos inclusiva (pessoas, parentes, grupos, povos, gente). Tudo leva a crer que, entre eles, os acidentes geográficos ou outras características locais servissem de epônimo para designar o subgrupo que ocupava o território correspondente. Referências aos sítios habitados pelos subgrupos ou seus membros aparecem nas narrativas de guerras, feitiços e migrações passadas, inclusive nas que versam sobre os eventos que culminaram em sua unificação há seis ou sete décadas (Fank \& Porta, 1996 b). O uso atual de tais apelativos, de maneira um pouco imprecisa, parece ainda traduzir uma certa inclinação residencial, na medida em que repousa ora nos vínculos mais estreitos com os parentes paternos, ora nos maternos, ora em ambos - todavia, aos bastardos (filhos nascidos fora da instituição matrimonial, inclusive no caso de viúvas), recusa-se-lhes a afiliação a qualquer dos subgrupos ${ }^{9}$.

Quanto ao etnônimo pelo qual são hoje conhecidos, tomaram-no na verdade de um subgrupo já extinto - os Sorowaha das margens do Cuniuá, de célebres xamãs. Se a princípio não era mais que uma boutade para satisfazer a curiosidade insistente dos indigenistas (Fank \& Porta, 1996 b: 241), tornou-se logo uma expressão de uso consagrado, também entre eles. Mas há ainda uns tantos inconformados, que recusam tal etnônimo sob o argumento decisivo que ali seriam todos Jokihidawa, afinal eles agora estão nas terras do igarapé Jokihi...

Durante a maior parte do ano os Sorowaha permanecem reunidos em uma das grandes casas cônicas que se erguem na zona central do seu território - uma típica zona de "terras firmes", irrigada por pequenos cursos d'água que anualmente ganham volume durante a estação chuvosa, de novembro a abril, e transbordam nos lagos e igapós que distraem uma topografia pouco acidentada. É no interior desse domicílio comum que a vida social (e talvez, sua cosmologia, cf. Kroemer, 1994: 29-30) se adensa, numa complexa teia de relações de parentesco, laços de amizade e múltiplas formas de convivência. Espaço da intimidade e da proximidade, ali os estrangeiros parecem sempre fora de lugar - impressão que ultrapassa um simples desconforto subjetivo, como mostra a pergunta nada trivial 
que, certa feita, nos fez Hamy: "Mas afinal por que vocês (as indigenistas e o antropólogo) vêm e ficam aqui, se não conheço suas famílias, nem vocês a minha?".

Na casa (oda) sem paredes laterais ou divisórias internas, cada família ocupa, de maneira mais ou menos aleatória (se possível, nas proximidades de consangüíneos de um dos cônjuges), uma das repartições domésticas (kaho) que circundam a planta arquitetônica. A casa pertence ao homem que a constrói, ele é o seu "dono" (anidawa) e se encarrega dos reparos necessários quando o grupo ali reside - período que varia entre alguns meses a pouco mais de um ano. Cerca de oito a dez casas estão contínua e simultaneamente sendo construídas ou reformadas, todas elas na zona central do seu território. Construir casas é um dos atributos da maturidade masculina; ao longo de sua vida um homem chegará a levantar quatro ou cinco delas. Para sua construção, que exige um a dois anos de dedicação e muito esforço, todos os homens colaboram na montagem da estrutura de madeira, ao passo que a cobertura de palhas caberá ao seu anidawa.

A categoria anidawa, além de "dono da casa", abrange também outras relações, como a propriedade da roça, a posse de objetos de valor (uma canoa, por exemplo) e a liderança nas caçadas e pescarias coletivas, e corresponde, em cada um desses casos, a certos direitos e deveres que orientam o curso da ação social.

Ao lado das incursões cotidianas e solitárias pelas trilhas que partem da aldeia, os caçadores sorowaha realizam duas modalidades de expedição venatória de maior envergadura: o kazabo, um acampamento para onde vão as famílias e que se prolonga por semanas, e o zawada, quando seguem apenas os homens para áreas mais distantes, por uma semana ou pouco mais. Na caça os Sorowaha utilizam basicamente um tipo de curare, com o qual lambuzam as flechas e os dardos da zarabatana. E na pesca, além de anzóis e linhas de náilon, também lançam mão de venenos vegetais e organizam pescarias coletivas. Para este fim, cultivam uma variedade de timbó (konaha, provavelmente uma leguminosa do gênero lonchocarpus, cujo princípio ativo é a rotenona) e uma outra de tingui (bakyma). Suas 
Revista de Antropologia, São Paulo, USP, 2000, v. 43 nº 1.

roças são diversificadas e extensas e nelas predominam variedades de mandioca, macaxeira, cana, banana e tubérculos. A coleta de uma imensa variedade de frutos silvestres, em todas as épocas do ano, complementa a farta pauta alimentar.

Seja nas atividades costumeiras ou em situações de crise, não se observou até o momento a instituição de uma chefia ou qualquer modelo de centralidade política. Neste ponto, sua organização social parece afastar-se da dos outros Arawa, entre os quais a chefia é uma função relevante (por exemplo, o tamine entre os Kulina, cf. Pollock, 1985: 54). Em seu lugar, no entanto, vigora entre os Sorowaha uma espécie de "ordem dos caçadores", de cunho hierárquico, que notabiliza os homens de acordo com a quantidade de antas que cada um já abateu. Essa espécie animal, convém notar, é para eles a caça por excelência, leitmotiv para um elaborado cerimonial de cozimento e distribuição. Além do prestígio que regularmente auferem, os melhores caçadores têm a primazia nas partilhas de carne, nas quais a sua posição no ranking cinegético determina, tanto quanto possível, o lugar na sequiência de distribuição e o quinhão que receberá.

Uma forte oposição contrapõe os homens às mulheres, valorizandoos desigualmente em muitos aspectos da vida social. Os filhos homens são, do ponto de vista de ambos os sexos, um motivo de legítimo orgulho, de tal forma que a exigência de tê-los é, por vezes, sustentada quase como uma obrigação moral, da qual não escapam sequer os forasteiros. De fato, um dos feitiços que as mulheres mais temem é, precisamente, o que lhes interdita a concepção de varões (Fank \& Porta, 1996 a: 38-9). E o próprio reconhecimento social do amadurecimento biológico de um indivíduo, isto é, a passagem às categorias etárias dogoawy, tem como parâmetro o ciclo de vida dos seus descendentes masculinos ${ }^{10}$. Tudo isso faz com que, no extremo oposto dessa escala de valores, o alvo primário do infanticídio seja do sexo feminino, o que é quase uma regra no caso de bastardas.

Na esfera ritual, a maturidade masculina (entre 12 e 14 anos) é sinalizada pela colocação do sokoady (“suspensório" peniano), um evento público 
que tematiza essencialmente as relações de afinidade. Após uma grande caçada ou pescaria, refeições coletivas e bailes, os rapazes recebem o adereço de cordéis de algodão e são então surrados pelos homens adultos (exceto seus consangüíneos). Daí, vão deitar-se em redes que são armadas no alto, na parte central da casa, enquanto seus consangüíneos participam de uma peleja contra os demais homens (estes, ornamentados, gesticulam como "macacos-barrigudos", e por isto este duelo ritual chama-se gaha), abraçando-os fortemente pelas costas. Na etapa final os rapazes são levados pelas mulheres para um banho no igarapé, onde cortam seus cabelos e os pintam de urucum; neste momento, os circunstantes gracejam insinuações sobre as eventuais relações sexuais do iniciado (Fank \& Porta, 1996 a: 14-20). Para o sexo oposto, ao contrário, a entrada na adolescência, com a chegada da primeira menstruação, implica sua reclusão e isolamento no âmago do espaço doméstico (com os olhos vendados, as meninas ficam deitadas na rede, quase não comem e apenas saem, em geral, à noite, para as necessidades fisiológicas). Mas é no controle efetivo da sexualidade feminina que, a rigor, as diferenças de gênero são reiteradas e se evidencia a submissão forçada das mulheres: seu comportamento sexual está sob constante vigilância, são frequientemente admoestadas por seus pais, irmãos ou outros parentes próximos e proibidas de saírem desacompanhadas, em razão da ameaça de "abuso sexual" por não-consangüíneos.

A oposição entre consangüíneos e afins, que se expressa ritualmente no momento da iniciação masculina (sokoady), corresponde a uma clara distinção conceptual no domínio do parentesco, no qual a terminologia caracteristicamente dravidiana ${ }^{11}$ repercute, nas gerações centrais, a regra positiva de casamento de primos cruzados. Contudo, em detrimento da nomenclatura de parentesco, no seu cotidiano os Sorowaha preferem geralmente o uso vocativo de nomes próprios ou certas tecnonímias. E, da mesma maneira, uma rara memória genealógica, que alcança cinco ou mais gerações passadas, enfatiza singularmente os nomes e apelidos - que raramente se repetem - e certos detalhes pitorescos de uma longa cadeia de ancestrais. Ao que tudo indica, estamos diante de uma deriva simbólica que focaliza essencialmente os indivíduos e os particulariza, consoante 
alguns traços pessoais selecionados de um catálogo predefinido (nome, atributos físicos, temperamento, habilidades etc.).

Em vários momentos e de diversas maneiras, no mesmo sentido, as virtudes pessoais e o desempenho individual são evocados, realçados e socialmente valorizados. $\mathrm{O}$ vigor juvenil é constante e ostensivamente exaltado e as exibições de força física acontecem amiúde - em particular, por ocasião das tarefas de construção da casa-, e delas participam até mesmo homens com idade mais avançada. Da mesma maneira, nos "rituais de carregamento" os homens e os rapazes, um a um, são obrigados a deslocar um volumoso feixe de cana ou um grande cesto abarrotado de massa de mandioca ralada (Fank \& Porta, 1996 a: 37). E, no campo dos juízos morais e estéticos, talvez se possa inferir uma operação de individualização muito semelhante: comentários corteses ou ferinos a respeito do comportamento alheio, ponderações sobre semelhanças físicas entre indivíduos, elogios a predicados das mais variadas e até bizarras partes da anatomia humana (as panturrilhas, por exemplo).

Em resumo, neste socius à primeira vista pouco diferenciado internamente, este breve survey etnográfico permitiu identificar ali certos mecanismos de individuação (nominação, genealogia, traços pessoais etc.), uma ordem hierárquica (o ranking dos caçadores), um princípio de desigualdade (que opõe homens e mulheres) e uma relação de troca (entre consangüíneos e afins). Veremos, adiante, o modo pelo qual estes vetores são tematizados pela prática de suicídio.

\section{Os números da morte voluntária}

Nos países industrializados a mortalidade anual por suicídio encontra-se entre uma faixa de incidência mínima, algo como 4 a 10 casos (Brasil, Itália), e uma máxima, cerca de 30 a 40 casos (Dinamarca, Hungria), taxas que são calculadas, de acordo com o padrão estatístico usual nos meios especializados, em relação a uma população de 100 mil habitantes. No Japão, por exemplo, notabilizado pela prática do seppuku (conhecido no 
Ocidente como haraquiri), um tipo de morte ritual que possibilita a restauração da honra pessoal e familiar (Pinguet, 1987), as taxas são de apenas 21,3 para os homens e de 10,1 para as mulheres, muito próximas portanto dos números franceses (Barros, 1991: 58).

Já entre adolescentes indígenas norte-americanos, vários pesquisadores salientaram que os índices são bem mais acentuados que a média geral naquele país. No Brasil, sabe-se da ocorrência de casos esparsos em vários grupos indígenas (Paresi, Tikuna, Yanomami), muito embora a questão tenha passado desapercebida até a década de 80 , quando se detectou um recrudescimento do suicídio entre os Guarani ${ }^{12}$ no Mato Grosso do Sul. No ano de 1995, talvez o mais crítico, houve entre estes um total de 55 casos fatais (CIMI, 1996: 36-8). Para uma população estimada em 25,5 mil nas áreas próximas à cidade de Dourados, isto equivaleria a uma taxa de 215,7 - algo como quarenta vezes as médias brasileiras ou dez vezes as taxas mais elevadas de países como a França e o Japão. Na América do Sul, taxas similares já haviam sido calculadas para os Aguaruna, da família lingüística Jívaro, que habitam a Amazônia peruana (Brown, 1986: 312).

A reduzida extensão das amostras e a baixa frequiência dos eventos, como se sabe, impõem cautelas ao manuseio de dados demográficos em sociedades de "pequena escala" (Adams \& Price, 1994). Mesmo assim, o que dizer do suicídio entre os Sorowaha, cujas cifras são quase dez vezes as taxas guarani, ou cem vezes os números do mundo industrializado? Ou seja, uma projeção aritmética de 1.922 casos para 100 mil habitantes! É verdade que, para sociedades de magnitude e feitio tão distintos, tal comparação não serve mais que uma ilustração para o problema. Maurice Halbwachs (1930), cujo Les causes du suicide foi saudado por Marcel Mauss como um complemento ao trabalho de Durkheim sobre o tema, já advertira que proporções iguais em diferentes meios sociais poderiam resultar de situações e motivos muito diversos, e vice-versa ${ }^{13}$. Vejamos então o que se passa entre os Sorowaha. 
Revista de Antropologia, São Paulo, USP, 2000, v. 43 nº 1.

De 1980 a 1995 houve entre eles um total de 38 óbitos por suicídio 18 homens e 20 mulheres -, em meio a uma população média de 123,6 pessoas $^{14}$. Durante o mesmo período, nasceram 101 crianças e morreram 66 pessoas ao todo. De um lado, portanto, uma alta taxa de natalidade (cerca de 6,3 nascimentos anuais); de outro, um crescimento demográfico pouco expressivo, em torno de 1,9\% ao ano. Quanto aos fatores de mortalidade, preponderam dois mecanismos eminentemente sociais: o infanticídio (5 casos, todos do sexo feminino, ou 7,6\% do total das causae mortis) e, sobretudo, a intensa prática de suicídio por envenenamento (38 casos, ou 57,6\% do total). Quanto aos demais fatores, dispersos e menos relevantes, contam-se problemas estomacais ( 4 casos), malária ou febre ( 3 casos), gripe (3 casos), anemia (3 casos), picada de cobra (2 casos), acidentes ( 2 casos) e causas variadas (6 casos). Para além de um simples epifenômeno, por conseguinte, esses números trazem evidências de uma certa constante, a regularidade da morte voluntária na sociedade sorowaha, ao mesmo tempo em que confirmam a ingestão de konaha como o modo imperativo de pôr termo à vida. Proposição quase forçosa, na verdade, ao verificarmos que, dentre a população adulta (pessoas acima de 12 anos) no mesmo período, os suicídios proporcionaram a extraordinária cifra de $84,4 \%$ de todos os óbitos nessa faixa (38 casos num total de 45).

No levantamento genealógico que remontou cinco ou seis gerações passadas $^{15}$, foram reportados 122 casos ( 75 homens e 47 mulheres) anteriores a 1980. Qualquer que seja o período em questão, todavia, observa-se que, em sua maioria, os suicidas eram jovens de ambos os sexos (isto é, nas categorias etárias wasi e atona, respectivamente rapazes e moças entre 14 e 28 anos; ver nota 10). A acentuada tendência suicidógena a que os jovens se inclinam não desperta, do ponto de vista nativo, qualquer surpresa. Os Sorowaha compartilham a firme opinião de que "wasi e atona gostam de tomar konaha; dogoawy não" (dogoawy, homens e mulheres maduros), como declarou Ohozyi, sem maiores rodeios. Tal pendor patentearia, de fato, certos postulados arraigados na filosofia de vida indígena, que enunciam um valor absoluto para essa etapa do ciclo biológico 
e, como corolário, a recusa peremptória (e um certo desprezo) à velhice e à decadência física. De acordo com os Sorowaha, por esta razão, "não é bom morrer velho, é bom morrer jovem e forte". De sorte que a orientação e os valores que exaltam a juventude e informam sua conduta radical mostram-se inteiramente congruentes com o comportamento estatístico dos suicidas, conforme os números consubstanciados abaixo:

\begin{tabular}{|l|c|c|c|c|}
\hline & \multicolumn{2}{|c|}{ Até 1979 } & \multicolumn{2}{c|}{1980 a 1995 } \\
\hline & Total de casos & $\mathrm{N}^{\mathrm{O}}$ de jovens & Total de casos & $\mathrm{N}^{\mathrm{O}}$ de jovens \\
\hline Homens & 75 & 53 & 18 & 15 \\
\hline Mulheres & 47 & 29 & 20 & 11 \\
\hline Soma & 122 & 82 & 38 & 26 \\
\hline
\end{tabular}

Quadro 1: Os jovens e o suicídio.

Este quadro, à primeira vista, indicaria uma maior propensão dos rapazes ao suicídio. No entanto, se distribuirmos esse conjunto de casos em faixas etárias mais estreitas (uma escala de $3 \mathrm{em} 3$ anos, por exemplo, conforme os gráficos abaixo), deparamo-nos com uma ligeira, mas não irrelevante discrepância no tocante à equação entre sexo e idade dos suicidas. De início, acentua-se uma tendência precoce entre as mulheres, com taxas mais elevadas dos 12 aos 17 anos. Deste ponto, as taxas femininas são sobrepujadas pela curva masculina ascendente, cujo pico máximo fica entre os 18 e os 20 anos, aproximadamente ${ }^{16}$. Dos 30 anos em diante, os eventos são mais esparsos, não obstante a ligeira predominância de vítimas mulheres. 


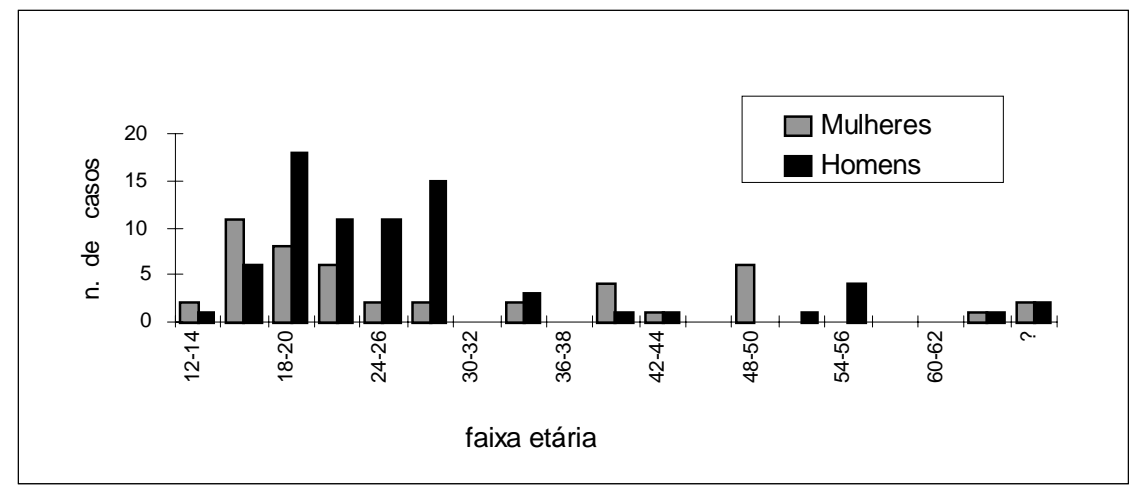

Gráfico 1: Suicídios por faixa etária até 1979.

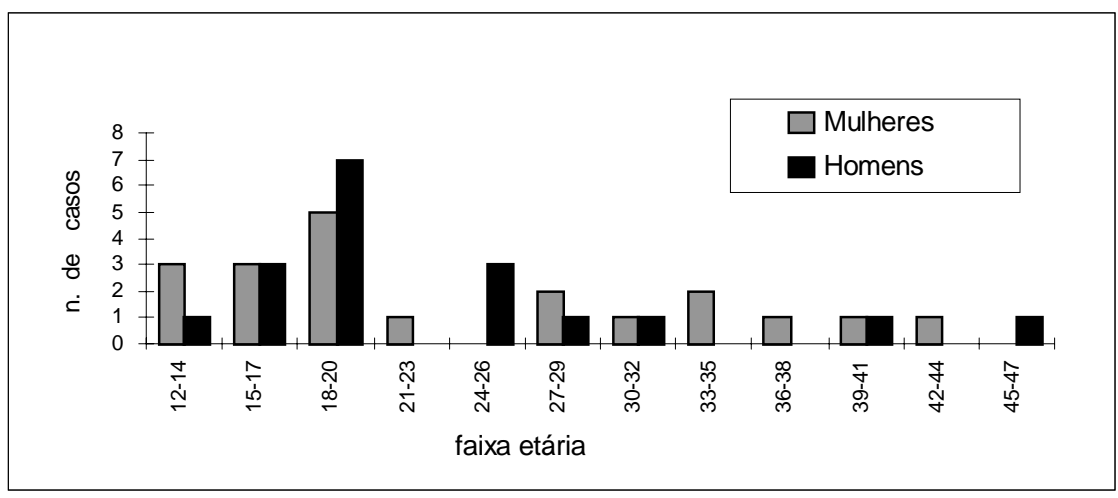

Gráfico 2: Suicídios por faixa etária de 1980 a 1995.

Observando tais afastamentos entre a curva feminina e a masculina, uma hipótese plausível seria explicá-los a partir dos dispositivos que diferenciam os gêneros nessa sociedade, notadamente os ritmos próprios, as marcas e os significados que são atribuídos ao amadurecimento sexual dos ado- 
lescentes. Assim, os ritos de passagem que contrastam os papéis masculino e feminino, as regras e obrigações respectivas a que estão submetidos, o status social desigual que os constrangem, as formas rigorosas de controle da sexualidade e as expectativas matrimoniais assaz divergentes que homens e mulheres vivenciam ${ }^{17}$. Deve-se observar que, entre os Sorowaha, os jovens de ambos os sexos atravessam um período bastante conturbado em suas relações com a família e com a coletividade, período que se inicia logo após os eventos que marcam seu ingresso diferenciado na vida adulta, ou seja, a imposição do sokoady para os rapazes e a primeira menstruação para as meninas, e que prossegue durante os primeiros anos de seu casamento - os desentendimentos conjugais e a convivência tensa com os afins, com efeito, compõem uma mistura assaz explosiva. Os atritos parecem diminuir com o nascimento dos primeiros filhos, quando os casais enfim alcançam uma certa estabilidade emocional (Fank \& Porta, 1996 a: 6).

De maneira que, nesses termos, há que se creditar à ênfase excepcional que a sociedade sorowaha empresta às virtudes físicas e morais, sobretudo as que conotam a juventude, a maior parte das e as mais perturbadoras tensões que afligem rapazes e moças, tão intensamente exigidos quanto ao seu desempenho individual (força física, habilidade, disposição, beleza, controle da sexualidade etc.) e, por isso mesmo, tão suscetíveis a eventuais desavenças e desgostos.

\section{A morte anunciada}

As tentativas de suicídio, em sua maior parte, respeitam um padrão bastante regular de conduta. Minhas observações durante a pesquisa de campo, os relatos dos informantes, as descrições disponíveis (Kroemer, 1989 e 1994; Silva, 1994 a e 1994 b), as anotações nos diários da equipe indigenista, todos registram uma sequiência quase invariável de ações e levam a conjeturar a morte voluntária entre os Sorowaha como um autêntico ritual auto-agressivo. O envenenamento, ou talvez intoxicação, dizem eles konaha bahi, "por causa do timbó", é o único meio utilizado para tal fim. 
Revista de Antropologia, São Paulo, USP, 2000, v. 43 nº 1.

\section{Já os passos trilhados pelo suicida, costumeiros e previsíveis em deter- minadas situações, podem ser decompostos em umas poucas unidades cênicas, ao modo de um script comportamental:}

1) um determinado acontecimento provoca irritação ou contrariedade;

2) o indivíduo então destrói seus pertences (corta e queima a rede, quebra suas armas e ferramentas, estilhaça os utensílios de cerâmica);

3) os circunstantes, parentes ou não, deixam-no extravasar sua agressividade; procuram disfarçar sua apreensão e, com estudada naturalidade, continuam suas atividades corriqueiras ou começam imediatamente alguma; eles evitam olhar diretamente ${ }^{18}$ para o raivoso, mas acompanham furtivamente seus movimentos;

4) se após o acesso catártico a raiva ou o desgosto ainda não o abandonou, o indivíduo emitirá um grito ou logo sairá ostensivamente da casa, correndo em direção a alguma roça para arrancar raízes de timbó;

5) os que acompanhavam discretamente o que se passava avisam os demais (parentes, talvez), e algumas pessoas (geralmente do mesmo sexo) perseguem o suicida ou, se este já está distante, procuram-no nos caminhos que vão dar às roças;

6) se os perseguidores o encontram, tentam tirar-lhe as raízes; caso contrário, o suicida se dirige a um córrego e ali espreme e mastiga o timbó, de modo a ingerir seu sumo; em seguida, bebe um pouco de água para ativar seus efeitos tóxicos;

7) daí, ele volta correndo rumo à casa (alguns não o conseguem, e desfalecem ou morrem no caminho);

8) ali chegando, o suicida é atendido por seus parentes ou outros, o que varia segundo os motivos e as relações que suscitaram a tentativa; a operação de salvamento consiste em provocar o vômito, irritando o esôfago com talos de folhas de abacaxi, esquentar o corpo com abanos aquecidos (tarefa realizada pelas mulheres), bater nos membros dormentes e gritar ao ouvido para despertá-lo, mantendo-o sempre sentado;

9) no curso do tratamento, em geral, as pessoas mostram-se zangadas com o suicida, falam-lhe agressivamente e xingam-no;

10) a eventual morte do suicida, todavia, espraia uma forte comoção e ganha expressão ritual através de chorosas melopéias (ohi; cf. Fank \& Porta, 1996 a: 34-7); o desfecho dramático motiva outras tantas pessoas (consangüíneos, afins, amigos) a realizar, logo em seguida ou passado algumas horas ou dias, novas tentativas de suicídio, as quais dão início a um novo ciclo de perseguições e medidas de salvamento. 
Os sintomas e as reações fisiológicas decorrentes do envenenamento, como pressão baixa, frialdade, convulsões e inchaço, são paulatinos e inspiram uma maior ou menor atenção ao paciente. A sua sobrevivência, no entanto, depende de circunstâncias variadas, entre as quais a firmeza de vontade, a quantidade ingerida, a resistência ao tratamento, a disponibilidade de pessoas aptas para socorrê-lo e o número de tentativas simultâneas em curso. Para melhor ilustrar a ritualística acima roteirizada, apresento a narrativa dos acontecimentos que marcaram o suicídio de Bosomaro em 1988, nas palavras de seu irmão Xiobori. Uma exegese nativa dos episódios, afora inevitáveis distorções no viés e nas palavras do entrevistado - seja pela tradução ou as alterações estilísticas -, talvez esclareça, muito decididamente, quais fatos e quais significados culturais são relevantes no enredo da morte voluntária.

\section{O suicídio de Bosomaro}

Passado algum tempo da morte por suicídio de seu najija Wanari (irmão mais velho classificatório, FFBSS), Bosomaro ainda continuava zangado. Aconteceu então que seu macaco-barrigudo se soltou e Bosomaro, com raiva, destruiu seus pertences e foi ingerir timbó.

"Ele ficou muito bravo (zawa nahyro). Não era bom. Ele quebrou o arco e as flechas, cortou a rede. Estava bravo. O macaco-barrigudo fugiu. O terçado que Suzuki [o missionário do JOCUM] deu e o outro terçado pequeno que Mário [o psicólogo que residia entre eles] trouxe, ele quebrou e depois saiu. Não vi para onde. Ele foi pelo caminho e longe pegou as raízes de konaha e espremeu na água. Bateu, espremeu e bebeu.

Os Sorowaha não viram. Ikiji foi e viu, os outros não viram. Somente Ikiji saiu atrás e o encontrou:

- Ikiji, o que você veio fazer aqui? - Bosomaro perguntou.

- Cadê o konaha? - perguntou então Ikiji.

- Eu não tomei konaha, estou apenas andando - respondeu.

Bosomaro veio correndo para casa. Os Sorowaha não o seguraram, todos estavam bravos porque ele tomou konaha. Não o pegaram [para fazer o tratamento]. Anya ficou bravo, mas os Sorowaha disseram que não era bonito ficar bravo. Então o pegaram. 
Revista de Antropologia, São Paulo, USP, 2000, v. 43 nº 1.

Eu era pequeno, cheguei em casa e o vi já morto. Eu fiquei bravo e fui tomar konaha, tomei um pouco. Ikiji me disse que era pouco. No outro dia eu saí para tomar mais konaha e Ohozyi me agarrou. Nakohany e Anya me pegaram. Gamoki amarrou [o cadáver], trouxe o caibro e amarrou. Depois aprontaram a cova. Era tarde quando os Sorowaha enterraram o morto.

Eu estava com muita saudade. Eu ainda não tinha pêlos pubianos, eu ainda não sabia fazer nada, eu era hawini (menino) quando me colocaram o sokoady (suspensório peniano). Koakoy convidou-me para pescar no igarapé Makoha, dizendo que lá tinha muita matrinxã. Eu disse que não queria ir porque estava com saudade do meu irmão. Koakoy então me mandou jogar fora a saudade (zamkamoni tosa), porque ainda era menino. Mas eu não joguei a saudade fora, a saudade era grande. Fomos para o Makoha, fizemos acampamento. Havia muitas matrinxãs. Pescamos e comemos. Depois voltamos pelo caminho do Sabá [trilha aberta por uma equipe da FUNAI]. Ali não tinha animais arborícolas nem anta. Estávamos voltando, lá acampamos. Estavam Kaboha, Hamjyhi, Zobydeho, Koakoy e eu. Somi já tinha ido embora. Dormimos no acampamento. Na manhã seguinte, saímos para caçar. Koakoy falou para Kaboha:

- Vamos ver o rio Cuniuá.

E Koakoy mandou-nos, eu, Hamjyhi e Zobydeho ver o igarapé Coxodoá. Havia muitos macacos-barrigudos. Fomos então atrás de Koakoy. Ele veio e atirou com a zarabatana, mas o veneno não prestava. Matou apenas um barrigudo." (versão resumida; Fank \& Porta, 1996 b: 226-9)

Os motivos que, em geral, indispõem o indivíduo com alguém, com o conjunto do grupo ou consigo mesmo ou o comovem de alguma maneira, e que são oferecidos como justificativas para as tentativas de suicídio, estão imbricados numa teia de sentimentos que, nessas situações específicas, apregoa-se abertamente: dentre outros, a afeição (kahy), a raiva (zawari), a saudade (kamonini), especialmente sob a forma de pesar pelos mortos, e a vergonha (kahkomy) ${ }^{19}$. Por ocasião das exéquias, a raiva e a saudade, que no relato de Xiobori traduzem seu sofrimento pela perda do irmão, arrebatam parentes e amigos, e com isto marcam as expressões de luto nesse universo cultural. A trágica morte de um suicida anima invariavelmente inúmeras outras tentativas, numa reação em cadeia que atinge parentes lineares, colaterais, afins ou mesmo amigos da vítima. O mesmo se passa, 
na verdade, em qualquer caso de falecimento, seja devido a picada de cobra, doença ou acidente. Isso faz das honras fúnebres um drama incomensurável, de difícil descrição (Silva, 1994 b), que redunda em embates entre potenciais suicidas e quem tenta salvá-los, em imputações de culpa a uns e outros, em ameaças e, até mesmo, em agressões físicas. De modo que, causa mor dos óbitos por suicídio, a morte de alguém desdobra-se quase sempre numa série de outras. Em 1985, após o suicídio de uma jovem escorraçada pela sogra, morreram sua irmã e a cunhada. Em 1986, o suicídio de um homem, revoltado com a esposa que não lhe fez comida, provocou a morte de um amigo e do pai classificatório deste. Em 1987, morreram a mãe e um amigo de um rapaz que se havia matado porque outros reclamaram das fezes do seu cachorro. No mesmo ano, duas adolescentes tomaram konaha porque a avó de uma censurou-lhe os deslizes sexuais, o que induziu à morte seu irmão. Em 1989, quando faleceu uma menina de picada de cobra, suicidaram-se o pai viúvo e dois sobrinhos deste (ZS e BS) - um rapaz de 14 anos e um homem casado. Três meses depois, a viúva do último, a irmã desta e o pai do rapaz também morreram. Duas semanas depois, a irmã de um dos homens falecidos anteriormente teve uma rusga com o marido e matou-se, sendo acompanhada por uma adolescente. Em 1992, um "dono de casa", atarantado com os trabalhos de manutenção da maloca, magoado com sua esposa e aborrecido com o desaparecimento de uma faca, suicidou-se e com ele dois irmãos, seu pai e um companheiro de geração. Por fim, tive informações sobre uma recente sequiência de suicídios em fins de 1996, em razão da morte de um rapaz recém-iniciado, picado de cobra no acampamento de caça: duas mulheres (entre elas, a mãe do rapaz), dois homens casados e duas moças solteiras ${ }^{20}$.

Um dos aspectos da questão, decerto, diz respeito ao lugar da morte voluntária no modelo cosmológico sorowaha. Neste, todos os seres vivos estão dotados de um princípio vital místico, seu karoji; e o karoji dos seres humanos é a própria "alma”, asoma. E a alma, de certa maneira, confunde-se com o "coração", giyzoboni, a sede das lembranças, das emoções, dos sentimentos, da verdade interior - um dia, disse-me Ody: 
Revista de Antropologia, São Paulo, USP, 2000, v. 43 nº 1.

"Você fala não, mas seu coração diz sim!" Quando alguém morre, o seu coração/alma abandona-o e, nas águas fundas dos igarapés, espera a chegada das chuvas, quando então desce os rios maiores e salta para mergulhar no céu (Fank \& Porta,1996 a: 2-3; 1996 b: passim). Segundo Gunter Kroemer (1994: 150-1), os Sorowaha concebem três caminhos distintos que atravessam o firmamento: o mazaro agi ("caminho da morte"), o percurso do sol, por onde seguem os que morrem de velhice; o konaha agi ("caminho do timbó"), a trajetória da lua, por onde vão os suicidas; e o koiri agiri ("caminho da cobra"), o rastro do arco-íris, a rota dos que morrem de picada de cobra. Com isso, o destino escatológico encontrase polarizado entre a casa do ancestral Bai, o Trovão, no patamar celeste superior, para os que ingerem veneno, onde as "almas" (asoma) reencontram seus parentes e vivem como os autênticos Konahamady (o "povo do timbó"), e a morada do ancestral Tiwijo, a leste, para onde seguem as almas dos que morrem de velhice. Os que foram picados por cobra, estes permanecem num espaço intermediário, o próprio arco-íris. A opção pela morada de Tiwijo, concebida como um caminho "penoso, onde os corações, sem achar sossego e paz, vagueiam” (ibid.: 78), possibilita, paradoxalmente, sua transformação em seres eternamente jovens. A fonte dessa juventude, dizem eles, é uma "comida doce" que as almas recebem ao chegar - a velhice apodrece no túmulo, junto com a pele do cadáver. Lá a vida é boa, as plantas agrícolas crescem sem esforço e a caça e a pesca são abundantes (Fank \& Porta, 1996 a: 3; 1996 b: 126-9). Mas, de acordo com Kroemer (ibid.: 78), seria na direção de Bai que os Sorowaha projetariam sua "verdadeira existência à qual ritos, cantos e rezas estão relacionados" - um mundo tomado pelas águas, segundo eles, onde as almas comem apenas raízes de timbó e se transformam em peixes, seu destino final (Fank \& Porta, 1996 b: 183-5).

A análise das relações metonímicas entre o veneno konaha, as águas e os peixes, bem como a metáfora que identifica os peixes aos humanos, certamente apontaria para uma reflexão sobre a noção de pessoa entre os Sorowaha. Todavia, interessa aqui, sobremaneira, verificar como tudo isso se articula numa ordem social determinada. Retomando então o corte 
sociológico do presente ensaio, trata-se de construir uma tipologia que, embora provisória, talvez possa esclarecer o rol de motivos que são alegados (às vezes dois ou três, que se somam ou se encadeiam) para a ingestão do konaha. Aqui me afasto, decididamente, da epistemologia durkheimiana.

A abordagem da questão, disse já Maurice Halbwachs (1930), não deveria olvidar os eventos ou estados anteriores às tentativas, uma vez que esses compõem um aspecto e um efeito da estrutura e do gênero de vida do grupo social: "os motivos individuais do suicídio não o são menos em relação com as causas gerais, e fazem parte do mesmo sistema", pondera o autor (: 513). Para os óbitos ocorridos entre 1980 e 1995, disponho de informações, mais ou menos detalhadas, sobre as circunstâncias, os motivos e as relações em foco: vários a partir de observações diretas (da equipe do Projeto Zuruaha e de Mário Lúcio da Silva), outros tantos de comentários espontâneos. Esses dados foram, também, checados em entrevistas com alguns informantes e, no quadro abaixo, estão agrupados em categorias mais ou menos explícitas, embora heterogêneas. Por exemplo, quando alguém se suicidou porque o irmão morreu no mesmo dia ou uma viúva que, meses depois, sentiu uma saudade insanável do marido, tais casos foram classificados como "luto". Uma das principais dificuldades a superar, para a construção de uma tipologia mais ou menos operacional, é que as explicações, após algum tempo, tornam-se mais elaboradas e complexas e outras razões podem ser adicionadas. O psicólogo Mário Lúcio da Silva viu nisso uma distinção entre "causa imediata" e outra que seria a "causa principal": no calor dos acontecimentos, a comunidade contenta-se com explicações circunstanciais, evitando transtornar ainda mais as relações entre seus membros; à distância, razões de outra ordem, mais fundamentais, poderiam ser discutidas de forma mais aberta (Silva, 1994 a: 8). Seja isto ou não, apoiando-me outra vez na opinião de Halbwachs, os motivos alegados não deixam de testemunhar, a seu modo, embora a posteriori, certos significados consuetudinários a partir dos quais a sociedade ajuíza os atos suicidas. 


\begin{tabular}{|l|c|c|c|}
\hline \multicolumn{1}{|c|}{ Motivos } & Homens & Mulheres & Total \\
\hline luto & 11 & 5 & 16 \\
\hline luto, briga de casal & 1 & 2 & 2 \\
\hline luto, viuvez & 1 & & 1 \\
\hline luto, briga com namorado da irmã & 1 & & 1 \\
\hline luto, briga de crianças & & 1 & 1 \\
\hline luto, fuga de xerimbabo & 1 & & 1 \\
\hline sexualidade & & 3 & 3 \\
\hline casamento & & 3 & 3 \\
\hline casamento, briga com sogra & & 1 & 1 \\
\hline casamento, briga com irmão & & 1 & 1 \\
\hline casamento do filho, desatenção & & 1 & 1 \\
\hline briga de casal & 1 & 1 & 2 \\
\hline desentendimento com a mãe, fome & & 1 & 1 \\
\hline desentendimento com filho & & 1 & 1 \\
\hline desentendimento & & 1 & 1 \\
\hline reclamação & 1 & & 1 \\
\hline roubo de faca, casamento, briga de casal & 1 & & 1 \\
\hline
\end{tabular}

\section{Quadro 2: Óbitos por suicídio, 1980-1995.}

Temos assim que, no período em pauta, as condutas lutuosas, como poderíamos chamá-las, responderam pela maioria absoluta dos óbitos tabulados. Em números, um total de 22 casos foram induzidos por falecimentos anteriores, ao passo que 6 casos estavam relacionados a problemas na consecução de alianças matrimoniais, 5 denunciavam crises conjugais e 3 diziam respeito ao controle da sexualidade feminina (em geral, a reação de moças solteiras). Outros motivos também estiveram presentes, ainda que sem maior expressão estatística: contrariedades familiares, briga de 
crianças, fuga de xerimbabo, roubo de faca, reclamação. Considerando agora a distribuição por sexo, salta à vista o fato de que, se a atitude lutuosa dominou majoritariamente as alegações masculinas (15 dentre 18 óbitos), já os motivos femininos dividiram-se entre o luto (7 óbitos) e o que, em termos mais vagos, seriam os dissabores domésticos (13 óbitos, excluindose os casos de dupla entrada).

No tocante às relações de parentesco para os 22 casos lutuosos (15 homens e 7 mulheres), cotejando para isso os vínculos entre o suicida (aqui tomado como Ego) e a pessoa falecida anteriormente e considerando indistintamente os cálculos diretos e os classificatórios, haveria um nítido predomínio das relações consangüíneas sobre as afins (17 parentes consangüíneos, 5 afins e um não identificado). E, dentre as relações consangüíneas, quase dois terços dos suicidas tinham-se como germanos dos falecidos.

\begin{tabular}{c|c|c|c|c|}
\cline { 2 - 5 } & Relações & Homens & Mulheres & Total \\
\hline \multirow{4}{*}{ Consanguiíneos } & F/M & 1 & 1 & 2 \\
& B & 4 & 1 & 5 \\
& Z & 1 & 3 & 4 \\
& S/D & 4 & 1 & 5 \\
\hline \multirow{5}{*}{ Afins } & H/W & 1 & 1 & 2 \\
& BW & - & 1 & 1 \\
& FZS & 1 & - & 1 \\
& MB & 1 & - & 1 \\
\hline \multirow{7}{*}{} & $?$ & 1 & - & 1 \\
\hline
\end{tabular}

Quadro 3: Parentesco e suicídio. 
A distinção entre suicídios efetivos e meras tentativas, como se sabe, tem suscitado um intenso e insolúvel debate entre os estudiosos, seja com relação às suas implicações psicológicas, seja quanto aos determinantes sociológicos do ato. Em Tikopia, em que a modalidade preferida de suicídio era a viagem solitária ao mar numa canoa, observou Raymond Firth que, embora sem uma linha nítida separando tais categorias, de alguma maneira as tentativas refletiam um certo cálculo quanto aos riscos e às possibilidades de salvamento: "Do ponto de vista da interpretação do suicídio, o que tal pessoa está fazendo é apostando nos acasos naturais e no seu crédito na sociedade"(1967: 137), diz então o autor. Entre os Sorowaha, aliás, registra-se um número de tentativas que excede, em muito, os casos fatais. Enquanto estes se contam em unidades, aquelas podem chegar a dezenas ou centenas anualmente (Silva, 1994 a: 8). Em certa ocasião, a equipe indigenista que lá atuava estimou que cerca de $60 \%$ dos membros do grupo - ou seja, praticamente todos os jovens e os adultos - ingeriram konaha após a morte de um pai e de um de seus filhos. Ao longo dos quatro meses de trabalho de campo, entre setembro de 1994 e janeiro de 1995, presenciei ou soube de um total de 16 tentativas - e, felizmente, nenhum óbito. Muito embora de modo reservado, os presentes procuram assuntar os motivos em questão, e assim sempre havia alguém para nos deixar a par dos fatos. Abaixo, uma lista sumária das justificativas para essas tentativas. 


\begin{tabular}{|l|c|c|c|}
\hline Motivos & Homens & Mulheres & Total \\
acidente do filho & 1 & 1 & 1 \\
acidente do irmão & 1 & & 1 \\
acidente, dores & 1 & 1 & 1 \\
briga com mãe, sexualidade & 1 & 1 & 1 \\
briga de casal & 1 & 1 \\
briga de casal, tentativa da esposa & 1 & 1 \\
briga de crianças & 1 & 1 \\
doença da filha & 1 & 1 \\
faca defeituosa & & 1 \\
falta de cooperação & & 1 \\
machucado pela filha & & 1 \\
ofensa, briga de casal & & 1 \\
sumiço de terçado & & 1 \\
\hline
\end{tabular}

Quadro 4: Tentativas de suicídio.

Temos aqui, como se vê, um quadro muito diverso do que foi discutido para os casos fatais, na medida em que condutas muito semelhantes orientam homens e mulheres e ocorre uma razoável dispersão nos motivos 
Revista de Antropologia, São Paulo, USP, 2000, v. 43 nº 1.

selecionados pelos pretensos candidatos ao suicídio, dentre os quais sobressaem as disputas domésticas, os acidentes e as doenças. Tal leque de pretextos, na sua distribuição e no seu conteúdo, aproxima-se qualitativamente do que foi assentado para as vinte mulheres que consumaram o suicídio no período de 1980 a 1995 . Explicando melhor, as tentativas inócuas e uma firme disposição de matar-se (no caso de mulheres) pouco se distinguem, posto que esta e aquelas tecem-se a partir das mesmas cenas de desavenças triviais e incidentes corriqueiros. É somente no inquérito das tentativas masculinas, então, que os mortos e seu cortejo de tristeza e de saudade, agravantes essenciais e insofismáveis, metem-se desabridamente de permeio, na condição de vetor principal da ação.

Olhando agora, em conjunto, os motivos especificados nos quadros das tentativas e dos casos fatais e generalizando os argumentos de que se servem os suicidas, dir-se-ia que seus atos são informados basicamente por conflitos e crises que, não nessa mesma escala de importância, envolvem o zelo pela propriedade (ferramentas, roças), o controle da sexualidade feminina, a auto-estima pessoal (ofensas, doenças, feiúra, insucessos), a aliança matrimonial (casamento e relacionamento conjugal) e, sobretudo, o sentimento profundo que une os vivos aos parentes falecidos. Com efeito, os Sorowaha são capazes de recordar uma coleção de incidentes e de interesses contrariados que, segundo eles, explicariam as razões e o contexto de um provável ato suicida ${ }^{21}$. Um dos nossos informantes, durante uma temporada fora da área, ao observar os trovões ${ }^{22}$ e as nuvens escuras de uma tarde chuvosa, expressou seu temor quanto a uma eventual tentativa de suicídio na aldeia e, prontamente, enumerou alguns possíveis autores e os desentendimentos então vigentes: quem estava com raiva de quem, o porquê etc. Nesses termos, a disposição para o suicídio, consoante a equação que o modelo nativo operacionaliza, insinua-se como a resposta adequada ou a alternativa possível para arrostar uma variada gama de conflitos e de tensões que, seja de natureza interpessoal ou não, transtornam de uma ou outra forma o curso da vida cotidiana.

Mas se os conflitos fornecem o pretexto, ou ao menos o pano de fundo para as tentativas, é contudo a realidade da morte que engendra as grandes 
crises, nas quais as tentativas simultâneas, que então se multiplicam, aumentam perigosamente os riscos de novos óbitos. Fatos dessa natureza, com efeito, são bastante freqüentes: uma seqüência de sete mortes que estimo haver sucedido na década de 40, uma de três no início e outra de sete no final da década de 50, além dos casos já citados em 1985, 1986, 1987, 1989, 1992 e 1996. De modo que, uma hipótese que sugere comparações interessantes com outras cosmologias sul-americanas, teríamos uma espécie de economia mortuária a governar a sociedade sorowaha - ao menos, seu lado masculino -, na medida em que são os mortos que, em grande escala, produzem os novos mortos através da resposta suicidógena ao luto e à tristeza. $\mathrm{O}$ suicida, com sua atitude temerária, posiciona-se em uma disputa que pode ser glosada como um cabo-de-guerra entre vivos e mortos. Estes, que o "puxam" para acompanhá-los no além, um movimento induzido pelo sentimento de pesar imediato ou pela saudade, que retorna tempos depois nas recordações e nos sonhos ${ }^{23}$. Aqueles, que tentam desesperadamente salvá-lo, ocasião em que extravasam sua raiva contra quem pretende abandoná-los. A posição intermediária entre este mundo e o além pode ser ilustrada pela história do suicídio de Dawari, personagem do passado recente (sua filha Amo, já bem idosa, faleceu de gripe em 1991) que, segundo dizem, teria estreado tal modalidade de auto-agressão entre os atuais Sorowaha:

\section{Dawari, o primeiro suicida}

Os Katukina (do rio Cuniuá) já praticavam o suicídio. Masanidawa, o avô de Xamtire, foi visitar os Katukina e lá viu um caçador azarado retornar para casa e, com raiva, ingerir konaha e morrer. Tempos depois, um segundo caçador agiu da mesma maneira.

Os Masanidawa (o subgrupo ao qual Masanidawa pertencia) não ingeriam timbó. Quando retornou para casa, Masanidawa experimentou beber água com timbó durante uma pescaria; desfaleceu mas reanimou-se pouco depois. Passado algum tempo, uns poucos Masanidawa mudaram-se para a casa 
dos Jokihidawa. Os Jokihidawa já tinham timbó, que havia sido dado por Mako, dos Sarakoadawa. Masanidawa contou aos Jokihidawa que os Katukina praticavam suicídio com suas raízes.

Naquela época, os Jokihidawa abandonaram o Xibiriwi e foram para a região do igarapé Watanaha. Ali se reuniram os Adamidawa, os Masanidawa, os Jokihidawa, os Sarakoadawa, os Korobidawa. Dawari era dos Adamidawa. Eles não tomavam timbó. Primeiro foi Xiana, uma mulher que tentou se suicidar: ela ficou com raiva do marido Xiomawi e ingeriu konaha; mas não morreu, apenas desfaleceu. Depois foi a vez de Dawari.

Jama (filho de Irohoi) morrera. Ele era Jokihidawa. Dawari falava que ele era seu irmão mais novo (classificatório). Jama era solteiro, bonito, ria muito, todos gostavam dele. Aconteceu que Morixia colocou feitiço em Mojawi (do subgrupo Yjanamamady), e este morreu. Então Waxime (irmão mais novo de Mojawi) colocou feitiço em Jama (irmão mais novo de Morixia). Jama teve malária, diarréia e vomitou sangue. Jama morreu e foi enterrado no Jokihi. Os Sorowaha mudaram então para o Watanaha. As pessoas ficaram com raiva de Waxime e queriam flechá-lo; uma flecha acertou numa corda perto dele; ele estava com medo e permanecia ausente de casa durante o dia. Dawari lamentava a morte de Jama, seu irmão mais novo classificatório. Dez dias depois Dawari foi com sua esposa Koxire e seu filho Habanywa pegar frutas no mato. Dawari subiu na árvore e Koxire ficou sozinha. Chegou então Waxime, para conversar com a esposa de Dawari. Lá de cima Dawari perguntou-lhe com quem estava conversando; e gritou: "Eu estou com raiva de Waxime; ele colocou feitiço no meu irmão mais novo que morreu. Minha raiva não acabou." E acrescentou: "O Waxime é seu marido. Eu estou com raiva." Dawari então passou para outra árvore e foi embora. Dizem que sua esposa Koxire manteve relações sexuais com Waxime.

Koxire voltou para casa com seu filho. Dawari estava deitado na sua rede. Koxire cortou-lhe a rede. Ele ficou com raiva e agarrou o braço de Koxire, queria quebrá-lo. Koxire chorou. Depois Dawari saiu e pegou timbó, pegou tingui, pegou tabaco (komady). Bateu o timbó, espremeu e colocou na água, depois pegou o tingui e espremeu; pegou o tabaco. Ele ameaçou as crianças que tomavam banho no lago: "Vocês vão tomar konaha primeiro." As crianças fugiram com medo.

Xihi, filho de Ari, correu para casa e contou que Dawari estava tomando konaha. Dawari então chegou em casa. Koxire ficou com raiva dele e queria flechá-lo. Dawari morreu. Depois, outras pessoas passaram a tomar konaha (versão resumida; Fank \& Porta, 1996 b: 129-37). 
Em resumo, as tentativas de suicídio oportunizam, entre os Sorowaha, um modo padronizado e plenamente inteligível de comportamento, nos mais variados contextos sociais. Assim, por exemplo, pode constituir uma resposta a um ato de violência de terceiros. Uma mãe, cujo filho foi levemente ferido por outra criança, talvez queira demonstrar sua revolta e por isso ameaça ingerir konaha. Assim reagem, da mesma maneira, as esposas agredidas pelos maridos ou acusadas de adultério. Muito embora os Sorowaha pareçam denegar a violência entre adultos, os raros casos documentados de embates físicos desaguaram, quase sempre, em tentativas de suicídio de ambos os contendores. Porém, em certas situações, a iniciativa para tomar konaha corresponderá a uma auto-punição, pois seu autor atribui-se responsabilidade pelo malefício que infligiu a outrem. Há aqui, aliás, uma certa analogia com o hábito de aspirar rapé, do qual os Sorowaha são verdadeiros aficcionados. Percebendo-se culpado de algo, uma pessoa pode resolver-se a tomar um porre de rapé, ou pode ser forçada a isso pelos demais, irritados com a conduta inconveniente. Da mesma forma, uma mãe insistirá com o próprio filho para tomar konaha, como desagravo às acusações de adultério que o atingem. Ou, então, ironicamente, recomenda-se esta solução à forasteira irritada com o sumiço do seu isqueiro. Eaté mesmo um homem, insatisfeito com sua aparência física, chegará a aventar a falta dos dentes frontais como pretexto para suicidarse. Ameaça sempre latente, portanto, dado o seu largo espectro de aplicação no curso da ação social, o temário do suicídio percola as conversas e os atos mais cotidianos e, como notou Kroemer (1989: 183, 185), está presente inclusive nos jogos e brincadeiras infantis - como a ingestão de pequenas quantidades de veneno e a simulação da morte.

\section{A sociedade dos suicidas}

Embora pouco difundida, a prática do suicídio não seria propriamente um expediente desconhecido na bacia do Tapauá e suas redondezas. Corroborando a versão sorowaha que transcrevi acima, de que se trata de um 
Revista de Antropologia, São Paulo, USP, 2000, v. 43 nº 1.

"empréstimo cultural" oriundo dos Catuquina (provavelmente um subgrupo Arawa), temos a informação concisa do auxiliar do SPI José Sant' Anna de Barros, que os visitou em 1930 no igarapé Coatá, um afluente do Cuniuá:

Sua crença [dos Catuquina] não é definida. Ele não teme nem a morte nem a Deus, tanto que não subsiste à moléstia que o prostre por mais de oito dias sem recorrer ao timbó para morrer imediatamente. (1930: 12)

Todavia, na vasta província etnográfica do Purus e do Juruá, conforme as investigações já realizadas, encontra-se disseminado um viés cultural aparentemente distinto, que preside o complexo mortuário e vincula as doenças, a violência e a morte a outros marcos institucionais. Para os Kulina, um povo também de língua Arawa, as tensões e os conflitos internos ao grupo aldeão estão diretamente associados às acusações de feitiçaria, anteriores ou futuras. Fórmula de máxima hostilidade xamânica ${ }^{24}$, que fundamenta a etiologia de doenças graves de pessoas adultas, o dori é descrito como um pequeno objeto que o dsopinejé manipula e injeta no corpo da vítima (Pollock, 1985). Já entre os Jamamadi dos igarapés Capana e Inauini, afluentes da margem esquerda do Purus, outro povo de língua Arawa: o "temor ao feitiço é generalizado" e "cada grupo teme o outro e atribui ao arabani a principal causa da mortalidade", diz a antropóloga Lucia Rangel (1994: 145). Segundo ela, as acusações contra xamãs de outros grupos locais, tanto quanto o homicídio do indiciado ou eventuais expedições guerreiras para eliminá-lo, fazem da feitiçaria (arabani), na verdade, um mecanismo de distanciamento e de cisão (ibid.: 161, 171). Também entre os Kanamari do Juruá, da família linguiística Katukina, as ameaças vêm de fora, de estranhos que se aproximam da aldeia para lançar as "pedras" djohko, causa das doenças e da morte. A função xamânica, com isto, acrescenta Edwin Reesing $(1991: 91,98)$ diz respeito às "relações exteriores, políticas, das unidades Djapa". É exatamente a mesma opinião de Donald Pollock (1992: 38), acerca dos Kulina. 
Tal concepção, como se fosse uma diplomacia mística para os negócios exteriores, estende-se igualmente ao cenário guianense, onde os xamãs caribe têm como obrigação, diz Peter Rivière (1984: 74-75) em sua síntese etnográfica, representar a aldeia nas negociações além-fronteira, com o mundo visível e com o mundo invisível. Observa o autor, entrementes, que o crescimento demográfico de um grupo local tende a aumentar a "chance de disputa", na medida em que o surgimento de doenças indica falhas nas relações sociais; e, se as suspeitas recaírem sobre co-residentes, a consequiência será a fissão da aldeia em grupos rivais - ou seja, a dinâmica que o feitiço imprime provocaria o deslocamento do que, num primeiro momento, está próximo e dentro, de maneira a convertê-lo, então, em exterioridade. No mesmo tom, Joanna Overing (1988) sustenta que, entre os Piaroa, a organização política do seu território está baseada na disputa faccional encenada pelos líderes xamãs, os quais trocam acusações de feitiçaria, à distância, sempre que alianças matrimoniais deterioradas podem provocar alterações nos alinhamentos residenciais.

Em suma, sob esta dupla perspectiva, de um dispositivo que fraciona os grupos e de uma relação que os opõe uns aos outros, a instituição xamânica parece efetivar, a seu modo, justamente aquelas formações sociais que melhor caracterizam as terras baixas sul-americanas, ou seja, grupos locais diminutos, dispersos, autônomos e ideologicamente endogâmicos. Em outras palavras, penso que esta configuração atomizada do socius, insistentemente descrita nos estudos etnográficos da Amazônia e das Guianas, deveria ser entendida, ainda que não de forma exclusiva ${ }^{25}$, enquanto um correlato sociológico do estratagema xamanístico. Entre aqui e lá, entre a sociedade e seu além, os xamãs ocupam um lugar ambíguo, donde o poder que os impregna é percebido como extra-social, uma força desterritorializada e quase incontrolável, que inspira não apenas indisfarçáveis atitudes de respeito e de medo, mas sobretudo fomenta um ordenamento sociológico peculiar.

Uma modalidade de homicídio através de feitiçaria - que se denomina mazaro bahi, "por causa da morte" - teria existido entre os Sorowaha no 
Revista de Antropologia, São Paulo, USP, 2000, v. 43 nº 1.

passado. Nos registros genealógicos foram identificados 13 óbitos atribuídos a feitiço ( 9 homens e 4 mulheres), e os mais recentes devem ter ocorrido entre fins dos anos 50 e início dos 60. E, nos relatos em que discorrem sobre os feitos dos seus grandes xamãs, o tema está associado, muitas vezes, a desavenças entre pessoas vinculadas a subgrupos distintos. Por exemplo, contam que Aga, dos Masanidawa, comeu um morcego enfeitiçado por Birikahowy, dos Jokihidawa. Com raiva, por causa do casamento deste com uma mulher Masanidawa, Aga apertara-o em demasia na luta do gaha (ver acima). Birikahowy, muito machucado, conseguiu ainda vingar-se, e ambos faleceram no mesmo instante (Fank \& Porta, 1996 b: 55-6). No episódio do suicídio de Dawari, apresentado acima, da mesma maneira, a agressão e a vingança contrapõem membros dos Jokihidawa, Adamidawa e Yjanamamady, com base em suas lealdades consangüíneas.

De uma perspectiva cronológica, porém, tal causa mortis vai rareando a partir da geração de Dawari (e com ela os iniwa hixa, os grandes xamãs), paralelamente ao aumento da mortalidade por suicídio. A despeito de sua periculosidade, os Sorowaha lamentam a falta dos seus iniwa hixa, cujo poder excepcional permitia-lhes viajar para lugares distantes, destruir seus inimigos e, inclusive, visitar o reino dos mortos. Os dois ou três homens a quem hoje atribuem qualidades xamânicas, dizem eles, não passam de iniwa hosokoni, xamãs fracos cujo desempenho restringe-se aos contatos com os espíritos korime que lhes ensinam cantos e que trazem notícias de paragens distantes (id. 1996 a: 37-8). Trata-se, então, de interrogar o sentido dessa transformação, de medir sua extensão e seus efeitos sociológicos.

Vejamos em resumo o quadro atual. À primeira vista, diríamos que, num certo plano da vida social, os Sorowaha agem como se formassem um conjunto bastante homogêneo e fortemente integrado. A construção da casa, as pescarias com timbó, as caçadas coletivas, o cerimonial de distribuição de carne de anta, os ritos agrícolas, as rodadas noturnas de rapé e a iniciação masculina (ibid.), bem como os esforços incessantes para que todas as famílias possam acomodar-se numa única aldeia - mesmo 
que, em certos momentos, haja outras casas também em condições de uso -, todas essas atividades manifestam, cada uma a seu modo, um dilatado e efetivo espírito corporativo ou de coesão social. A simples idéia de permanecer sozinho à noite, em algum lugar fora da aldeia, provoca pânico em amigos e parentes. Este temor que os domina, e que a todo instante se renova, pois não se cansam de especular sobre possíveis agressões oriundas do exterior da sociedade (espíritos zamady, grupos indígenas hostis, sorveiros), reitera as concepções que, como vimos, proliferam na paisagem etnográfica regional. O receio de confrontos com essas formas de alteridade é, de fato, uma das razões que os próprios Sorowaha divisam para o isolamento e a permanência na área atual, ao longo de mais de cinco décadas, praticamente confinados em uma pequena extensão do território original.

Não obstante tal modelo de unidade e coesão, o uso recorrente do konaha emerge propriamente como um contraponto veraz à sua reificação idealizada. Desse ponto de vista, portanto, esboça-se uma outra dimensão analítica, mais profunda e decisiva, na qual uma certa divisão social se produz, intermitente mas assídua, mediatizada pelo gesto suicida. Ao contrário, porém, da (impensável, para os Sorowaha) fragmentação e oposição entre as partes à moda xamânica, trata-se de uma operação que interioriza e propaga a dissensão nos limites do grupo local, discriminando os componentes mais elementares da estrutura social e, afinal, vincando as relações intersubjetivas com sua marca indelével. Daqui em diante, todo ato e todo discurso estarão condicionados ao que se poderia chamar de potencial suicidógeno - a medida de eficácia e o parâmetro de valor com os quais se calcula a probabilidade de causar contrariedades ou danos, a si e a outrem. Em uma sugestiva auto-imagem, desta feita, os Sorowaha reflexionam às vezes sobre sua semelhança com os peixes, ambos vítimas do timbó ${ }^{26}$. Nesses termos, é a sociedade como um todo que se projeta através de um gesto reconhecidamente individualizante (uma tentativa é o bastante!): um suicida que se precipita no epicentro da ação social, ponto focal para o qual convergem atores, 
posições e relações, segundo um sistema de atitudes e de valores padronizados. A cada tentativa, os indivíduos ocupam ou permutam suas respectivas posições, buscando atender tanto as relações parentais e pessoais quanto seus comprometimentos naquela conjuntura particular. De modo que, além da atuação do próprio suicida, seria possível aí discernir, indutivamente, as seguintes funções:

1) os suicidas potenciais: em geral, os consangüíneos ou afins que, tensos mas impassíveis, aguardam o desenrolar dos acontecimentos (uns por estarem implicados nos motivos da tentativa, outros em vista de sua proximidade com o suicida pivô);

2) os solidários: os que correm para impedir a ingestão do konaha, perseguindo o suicida, ou que ajudam no tratamento;

3) os indiferentes: aqueles que permanecem distantes, uma vez que a crise não lhes diz respeito.

Creio ser esta a sociologia que, nesses momentos de extremo paroxismo, quando uma convulsão de gritos, corre-corre e gestos desesperados saturam agudamente o ambiente, possibilita alguma inteligibilidade a toda a variedade de reações individuais que ali se observa. De maneira que, numa paráfrase ao esquema de reciprocidades proposto por Sahlins (1965), é como se as medidas de assistência ao suicida sorowaha fossem organizadas segundo genuínos círculos concêntricos de solidariedade, do mais próximo ao mais distante, numa escala decrescente: solidariedade generalizada, solidariedade equilibrada e solidariedade negativa. Os suicidas potenciais, prontos a iniciar sua própria tentativa ao primeiro sinal de agravamento do estado do suicida antecedente. Os solidários, diligentes e preocupados, em maior ou menor número, conforme as circunstâncias. Mas quem há pouco perseguia e socorria o irmão ou um parente mais distante, no momento seguinte pode ser avistado correndo às roças de konaha, pois ele, como o anterior, urde motivos idênticos, ou porventura ainda outros, suficientes para instigá-lo em sua própria tentativa. Ao localizar o suicida no vértice trágico de um processo de diferenciação social, o modelo aqui descrito dispensa qualquer visão "epidêmica" ou de ação 
coletiva, com as quais se pretendeu descrever o fenômeno (Kroemer, 1994: 79). E em termos funcionais, é também capaz de explicar porque a probabilidade de óbitos cresce à medida que o número de suicidas potenciais aumenta, visto que diminui na mesma proporção a disponibilidade de assistentes solidários.

O comportamento suicidógeno entre os Sorowaha, desse modo, não caracterizaria qualquer desregramento ou disfunção, muito menos um comportamento desviante, conquanto subentende determinados princípios estruturais que singularizam o corpo social, a saber: a oposição entre vivos e mortos, quando nas tentativas está em jogo a relação com algum morto e, no salvamento, a incumbência dos vivos de zelar pelo suicida; a assimetria entre consangüíneos e afins, com ênfase nos laços de descendência e germanidade; a dinâmica etária, que distingue jovens e velhos, em particular quanto ao destino póstumo; o status social, que pode ocasionar maior indiferença ou aumento do número de suicidas potenciais; e o confronto entre os gêneros, que é exacerbado nessas ocasiões ${ }^{27}$.

Todo esse conjunto de fatos, enfim, deve tornar admissível, ao menos como hipótese de trabalho, $\mathrm{o}$ argumento de que o suicídio instalaria, firmemente, a diferença no interior do socius, ao mesmo tempo em que o totalizaria, às expensas porém de um ato ritual notadamente individualizador.

\section{Conclusões}

O estudo emérito de Durkheim objetivava, quanto ao método, a compreensão sociológica de um fenômeno que, visto até então como disperso e aleatório, não recebera outra explicação além de reduções a particularidades ou a disfunções individuais. A tipologia durkheimiana, ao invés, consoante as "causas sociais" que, do ponto de vista do autor, determinavam globalmente as taxas de suicídio, compromete-se diretamente com as equações fixadas pelo binômio indivíduo versus sociedade. Sumariamente, os tipos principais poderiam ser definidos da seguinte maneira: 
Revista de Antropologia, São Paulo, USP, 2000, v. 43 nº 1.

- o suicídio egoísta: resultado de uma individuação excessiva, diante da atomização do socius e da ênfase na autonomia das consciências individuais (1993: 158-9, 223);

- o suicídio altruísta: percebido como um dever e um gesto impessoal, devido à subordinação do indivíduo aos fins sociais (ibid.: 236-8, 240); e,

- o suicídio anômico: associado a desregramento, crises e mudanças, cujas origens estão no enfraquecimento da malha social (ibid.: 271, 281).

Tanto no suicídio egoísta quanto no suicídio anômico, afirma Durkheim, em ambos "a sociedade não está suficientemente presente nos indivíduos": para aquele, são as atividades coletivas que lhe faltam; para este, são as paixões individuais que se perderam (ibid.: 288). Já o suicídio altruísta efetuar-se-ia, em grande medida, nas sociedades "primitivas", nas quais a parte encontra-se submetida ao todo, o indivíduo absorvido pelo social (ibid.: 260, 416). Exemplo ímpar desta modalidade seria a epopéia kamikaze, durante a Segunda Guerra Mundial, na qual os pilotos japoneses ofertavam sua vida à glória do imperador, símbolo maior da pátria ameaçada, arremessando seus aviões contra os navios inimigos (Pinguet, 1987: 329, 334). Para Durkheim, propriamente, o tipo altruísta não comportaria mais que um rito sacrificial, um ato de abnegação, de submissão aos ditames do grupo social (1977: 24). Enfim, é como se o suicídio existisse apenas, e tão-somente, ali onde o indivíduo também está presente, na medida em que um ato dessa natureza subtenderia, necessariamente, autonomia, consciência e vontade individualizada ${ }^{28}$. Estamos assim de volta, é o que parece, aos próprios termos com os quais o autor equacionou sociologicamente o fenômeno.

Coerente e exaustiva, a tipologia durkheimiana denota sobretudo o paradigma teórico que a orientou, uma dicotomia ontológica entre a sociedade e os indivíduos. Conceptualizada como dois níveis de realidade distintos, mas que se interpenetram, tal dualidade constitui-se, na verdade, na pedra angular que sustenta toda a sua sociologia (Lukes, 1977: 32). Com efeito, tanto os conceitos de solidariedade orgânica e solidariedade mecânica, que tipificam suas fórmulas globais de sociabilidade, quanto o 
papel da consciência coletiva e a noção de representação social, elaborados por Durkheim em trabalhos posteriores, evocam como referência básica essa mesma fórmula dual (Cohn, 1997). Em Le suicide, todavia, é onde esta antinomia encontra-se mais exacerbada:

Duas forças antagônicas estão presentes. Uma vem da coletividade e procura apoderar-se do indivíduo; a outra vem do indivíduo e repele a precedente. (1993: 360)

Daí que, para Durkheim, o problema do suicídio, enquanto fato social, está situado justamente na articulação ou no grau de integração desses dois pólos. De maneira muito esquemática, teríamos então: no suicídio egoísta, puro individualismo, o indivíduo escapa aos ditames sociais; no suicídio anômico, a malha social se desfaz e as motivações individuais se perdem, num momento de transição e de realinhamentos; e no suicídio altruísta, quase uma forma de sacrifício, a sociedade alcança sua expressão máxima, obscurecendo as individualidades. Destarte, uma competição insolúvel, intrínseca ao próprio modelo sociológico, parece contrapor incessantemente os interesses individuais às compulsões sociais ${ }^{29}$. Tendo isso presente, poderíamos agora reescrever a tipologia durkheimiana, num plano mais abstrato, enquanto um conjunto de permutações matriciais das variáveis indivíduo e sociedade:

\begin{tabular}{|c|c|c|}
\hline tipo & indivíduo & sociedade \\
\hline egoísta & + & - \\
\hline altruísta & - & + \\
\hline anômico & - & - \\
\hline
\end{tabular}

Argumento central para o modelo analítico, a estabilidade das taxas representa, para Durkheim, o elemento objetivo que atestaria o caráter social do suicídio: a cada sociedade uma cifra constante, singularmente 
Revista de Antropologia, São Paulo, USP, 2000, v. 43 nº 1.

distribuída entre suas diversas partes. Assim protestantes se suicidam mais que católicos, divorciados mais que casados, há mais suicídios no verão que no inverno. Ao restituir os termos do próprio esquema analítico, contudo, a interpretação dos fatos arrisca-se em fórmulas quase tautológicas: ou há mais suicídios porque se intensifica a vida social (no verão) ou, inversamente, porque há mais individuação (no caso dos protestantes) ou, se nem uma nem outra, porque se afrouxam os liames sociais (nas crises ou passagens, como a separação, a viuvez, a falência etc.).

Ainda sobre esta tipologia, convém ressalvar um último aspecto, quase ignorado pelos comentaristas: para uma matriz com duas variáveis (indivíduo e sociedade) e uma alternativa binária (positivo ou negativo), como a que Durkheim utilizou para diagramar o fenômeno da morte voluntária, tal operação lógica deveria proporcionar, necessariamente, quatro possibilidades combinatórias. Há uma outra opção a considerar, portanto, na qual as duas variáveis estarão acentuadas positivamente. Aliás, a questão não passou despercebida ao próprio autor que, em uma nota de rodapé (1993: 311, nota 1), apontou a existência de um quarto tipo, o suicídio fatalista, designação que salientaria propriedades opostas à anomia. Resultado de "um excesso de regulamentação", Durkheim não lhe advertiu exceto o interesse histórico, uma forma de morte voluntária típica de escravos submetidos a uma disciplina opressiva, sem outras saídas. Outros exemplos etnográficos coligidos desde então, entrementes, poderiam ser aqui aduzidos. Como um certo tipo de morte voluntária na África (Jeffreys, 1952), designado como suicídio sansônico, que se pensava incompatível com o esquema durkheimiano - concebido enquanto uma sagaz vingança, a partir da crença de que esta seria possível ou na condição de fantasma ou na aplicação de sanções sociais ao culpado pelo agravo. Ora, o suicídio fatalista de Durkheim assim como o suicídio sansônico de Jeffreys, não obstante alguns traços particulares, ambos presumem a intervenção simultânea do indivíduo e da ordem social, a expressão concomitante das partes e do todo, e por esta razão deveriam ser aproximados ${ }^{30}$. Tal me parece, também, o caso sorowaha. 
A esta modalidade de morte voluntária, que mediatiza globalmente as relações sociais, singularizando-as dramaticamente através de processos de individuação e de totalização como os descritos para os Sorowaha, caberia talvez chamá-la de suicídio tópico, no sentido de um lugar comum e de um tema de interesse. Uma forma de sociabilidade e, quiçá, uma cosmologia. Passados tantos anos do corajoso estudo de Halbwachs (1930), é preciso todavia retomar sua lição metodológica, sua insistência quanto aos significados sociais dos eventos ou estados que antecedem as tentativas de cada suicídio, os motivos individuais, os pretextos comezinhos, as ocasiões particulares, já que estes indubitavelmente decorrem da própria armadura da sociedade. Porque não parece possível compreender o suicídio enquanto fato social e, ao mesmo tempo, como quiseram Durkheim e tantos que se debruçaram sobre a questão, deduzi-lo entretanto como um resultado (indesejado) do funcionamento (normal ou anômico) da sociedade, um flagelo social que viria da exacerbação ou da recusa dos princípios que a regem (Durkheim, 1977: 24-7). No cerne da questão, sem dúvida, deparamo-nos com o postulado intangível, partilhado pelas ciências e pelo senso comum ocidental, que concede um valor absoluto à vida ("instinto de conservação"), o que faz do suicídio, naturalmente, um índice de infelicidade, um sintoma que comprova senão o fracasso do indivíduo, então a derrota da sociedade. A etnografia sorowaha, nos termos em que se coloca, decididamente não corrobora tais assertivas.

Sem pretender retomar aqui as muitas críticas aos conceitos de sociedade e de indivíduo como categorias de pensamento universalmente válidas, recordaria, tão-somente, que a noção de pessoa em Marcel Mauss (1974) almejava relativizar o lugar, a forma e o conteúdo do sujeito no socius; e que a sociedade dos indivíduos, de cunho mais radical, segundo a formulação de Norbert Elias (1994), buscava superar a concepção ambivalente que permeia o pensamento ocidental e que opõe, aprioristicamente, os indivíduos à sociedade ${ }^{31}$. Além do interesse teórico mais geral, no entanto, há aqui um outro problema que, muito diretamente, diz respeito à etnologia sul-americana. Trata-se da primazia que, no afã de uma síntese das feições que peculiarizam as sociedades indígenas brasileiras, 
Revista de Antropologia, São Paulo, USP, 2000, v. 43 nº 1.

concedeu-se às idéias de construção da pessoa e de corporalidade (Seeger, Da Matta e Viveiros de Castro, 1979). Tal posição, num contexto muito diverso, retoma solidamente a tese dumontiana acerca da natureza das concepções holísticas das sociedades tradicionais, distintas social e historicamente do individualismo ocidental - aquelas, exprimindo relações que se subordinam à totalidade; este, dominado pela vertente individualizada de pessoa, foco central da vida social. De modo que, diz Louis Dumont:

O Indivíduo, refiro-me ao indivíduo humano como valor, só aparece na ideologia das sociedades modernas. (1985: 215)

No entanto, ao acolher a noção de pessoa como a via básica para a compreensão das sociedades indígenas, porque intrínseca à sua organização social e à sua cosmologia, esta perspectiva etnológica também teria identificado certas figuras ditas liminares, como o chefe, o xamã, o bruxo e o cantador, que subsistiriam em espaços sociais individualizados, de caráter adstrito e excepcional:

...é nestes papéis sociais que o sistema tribal recupera e constrói algo parecido com o nosso indivíduo: a pessoa fora do grupo, refletindo sobre ele e, por isso mesmo, sendo capaz de modificá-lo e guiá-lo. (Seeger, Da Matta, Viveiros de Castro, ibid.: 15)

Tais heróis fora-do-mundo que, segundo os autores, atuariam nesse contexto etnográfico com base numa vertente individualizada da pessoa, preenchem aqui funções homólogas, mutatis mutandis, às do "renunciante", na clave indiana de Dumont, alguém que abandonou a vida social e se basta

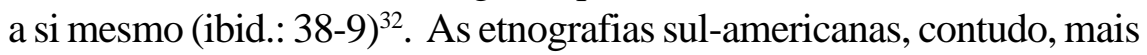
adensadas na atualidade, estão longe de sugerir indícios suficientes para tais paralelos. Por outro lado, a opção pela noção de pessoa, enquanto acesso privilegiado à compreensão das concepções ameríndias, padeceria ainda de um certo mal congênito. Pois, ao banir do horizonte sociológico as suas figuras centrais (o chefe, o xamã etc.), não resiste à tentação de recuperar, desta feita por contrabando, justamente a oposição entre o 
indivíduo e a pessoa, para assim explicar os resíduos que surgem quando o ângulo analítico se estreita em demasia ${ }^{33}$. Para melhor esclarecer este ponto, vejamos o caso da função xamânica. Na medida em que esta função seja referida estritamente aos seus aspectos empíricos mais imediatos, como as terapias corporais, as manipulações esotéricas de atributos pessoais ou a causação de doenças, abandona-se precisamente as suas implicações sociológicas mais gerais, o seu lugar de mediação nas relações entre grupos locais. Considero algo apressado, portanto, tal postulado de uma dominância da noção de pessoa entre os ameríndios, na medida em que passa ao largo de formas de ordenamento social e político que, decisivamente, ultrapassam as fronteiras mais imediatas.

Os dados sorowaha, ademais, fornecem um firme contra-exemplo, uma evidência etnográfica de que certas formas de individualidade generalizada são igualmente possíveis entre as sociedades indígenas brasileiras. Pois os suicidas, como espero haver esclarecido, não são figuras liminares, e nem exceções à regra. Trágica e volátil, a dimensão sociológica estaria aqui decisivamente determinada a partir de seus atos intrépidos, que arrebatam completamente a vida coletiva e a individualizam - muito embora, de acordo com propriedades muito diversas das que vigoram nas chamadas "sociedades modernas".

Retomarei aqui alguns pontos, indispensáveis porém à argumentação. Até as primeiras décadas do século XX os antepassados dos Sorowaha organizavam-se em diversos grupos locais, assentados em territórios próprios, e seus litígios, em particular quando envolviam estrangeiros, demandavam o agenciamento de feiticeiros. Com isto, as doenças e a morte eram atribuídas à sua ação malévola, à sua capacidade de controlar o mazaro bahi. Já na atualidade, encontramos apenas uma unidade social e territorial, e o suicídio como a causa mortis mais relevante. De sorte que, no curso das mudanças que então houveram, tanto no padrão de povoamento como no campo das relações com o exterior, algo inesperado aconteceu. De plano, há que se observar que a unificação dos remanescentes de grupos distintos teve como conseqüências imediatas, de um lado, o 
adensamento e a intensificação da vida social (interações, deveres, querelas) e, de outro, o enclaustramento que instituiu um modo de vida social "entre outros", o que significa dizer, cheio de sobressaltos e riscos - devo lembrar que, nessa como em províncias etnográficas contíguas, o perigo vem quase sempre de fora, dos Outros; mas, neste caso, os de fora estão dentro e os Outros são os vizinhos de kaho. Talvez alhures encontremos exemplos bastante semelhantes: entre os Ankave e os Baruya, de acordo com um instigante estudo comparativo de Bonnemère (1992) - a despeito da análise limitada às flexões de gênero nessas sociedades -, os padrões de povoamento ou residência seriam igualmente congruentes com as modalidades de violência ali vigentes. Os Ankave, nos quais ocorrem homicídios entre homens, moram regularmente em abrigos provisórios e dispersos pela floresta, ao passo que os Baruya, coagidos pelo suicídio de mulheres, vivem em grandes aldeamentos.

Embora esteja fora de questão especular acerca de uma gênese histórica para a prática do suicídio nos Sorowaha, não se pode deixar de assinalar as conexões estruturais entre este fenômeno e as transformações sociais e políticas que ali ocorreram. Grosso modo, existiria uma correlação genuína entre a configuração social anterior, composta de múltiplos grupos locais, e o exercício das atividades xamânicas, tanto quanto entre o agregado único atual e os atos suicidas. Na primeira, o poder dos xamãs desenvolve-se como uma mediação que se diria interlocal, através de dispositivos de cisão e de oposição que articulam e, assim, totalizam os diferentes coletivos. No segundo, sucede uma operação análoga porém no domínio interno, na medida em que a ameaça latente do suicídio regula as relações interpessoais, opondo desta feita pessoa a pessoa, e estrema assim as individualidades. Nesse novo quadro, de um lado, a feitiçaria demonstra-se uma impossibilidade lógica: daí a debilidade dos feiticeiros, porque eles e sua arte não têm mais lugar num coletivo unificado e, seja por princípio ou por escolha, agora indivisível. E, de outro, o suicídio poderia ser visto enquanto uma certa forma variante de feitiço, já que existem indícios de uma associação simbólica entre eles: como explicou Ohozyi, o karoji (princípio 
vital místico) do timbó “é xamã”, donde seus poderes para apossar-se dos corações humanos (Fank \& Porta, 1996 b: 182-7).

Se tudo isso é verdade, então haveria que se repensar o estatuto singular e original outorgado ao individualismo e, desde logo, recusar a sua reificação como apanágio privativo da civilização ocidental. Em outras palavras, é preciso considerar seriamente a contingência de diferentes e específicas modalidades de individualismo, inclusive dentre as configurações sociais tradicionais, do mesmo modo que ajuizamos a legião de holismos que os antropólogos já inventariaram, em todos os quadrantes. Em suma, é este o ponto principal aqui defendido, haveria outros indivíduos fora do Ocidente - ao menos, é o que dizem os radicais suicidas sorowaha.

\section{Notas}

1 Algumas idéias preliminares, numa primeira versão deste ensaio, foram discutidas no GT "Questões Atuais da Etnologia Indígena da América do Sul Tropical”, por ocasião da XX Reunião Brasileira de Antropologia, em Salvador (BA), 1996. Uma nova versão foi apresentada no Seminário Temático "Horizontes da Etnologia Indígena: Cosmologias e Formas de Sociabilidade na América do Sul", durante o XXI Encontro Anual da Associação de PósGraduação e Pesquisa em Ciências Sociais (ANPOCS), em Caxambu (MG), 1997. Além dos colegas que estiveram nestes eventos, agradeço ainda a Mário Lúcio da Silva, pelos comentários a um primeiro esboço, a Edmundo Peggion, com quem debati muitas dúvidas, e a Márcio Silva, pelas sugestões críticas para a presente versão. O título faz alusão ao conto de Gabriel Garcia Márquez, uma trama homicida cujos passos, embora noticiados de antemão, a inércia e o acaso conduzem a um desfecho trágico e, afinal, inevitável.

2 A pesquisa de campo entre os Sorowaha correspondeu a um período de pouco mais de quatro meses, entre setembro de 1994 e janeiro de 1995. Uma curta visita em maio de 1991, para uma avaliação do andamento dos trabalhos indigenistas na região, trouxera motivos mais que suficientes para uma investigação etnológica mais demorada. A viagem e a estadia na área indígena foram possíveis com o apoio da equipe do Projeto Zuruaha, então composta de Jonia Fank e Edinéia L. Porta. Com elas compartilhei informações, análises e opiniões, bem como a convivência naquelas distantes 
Revista de Antropologia, São Paulo, USP, 2000, v. 43 nº 1.

paragens da Amazônia. Com dados que elas e Mário Lúcio da Silva levantaram, havíamos anteriormente elaborado um extenso Cadastro Genealógico (aqui, largamente utilizado), depois conferido e corrigido em campo. Tive ainda a oportunidade de acompanhar a organização de seu material etnográfico, a transcrição de mitos e outras narrativas e a consolidação de um vocabulário preliminar (Fank \& Porta 1996 a; 1996 b; 1996 c) - um cabedal significativo, que utilizei largamente aqui. E Ednelson Pereira, que durante dois anos compusera aquela equipe indigenista, também permitiu-me gentilmente consultar seus diários de campo.

3 Sérgio Levcovitz (1998) apontou a "ótica essencialmente negativa" adotada nos estudos sobre o suicídio indígena (: 223), e assim propôs como chave de leitura para o estudo do fenômeno entre os Guarani-Kaiowá, da região de Dourados (MS), a noção de pessoa Tupi-Guarani, uma dialética do devirOutro que se realizaria ora no complexo guerreiro-antropofágico ora na migração à Terra-Sem-Males. A hipótese do autor, que não deixa de ser engenhosa, carece porém de uma demonstração a partir dos casos ali documentados, os seus contextos, os motivos e a exegese nativa.

4 O Projeto Zuruaha é um programa de ações assistenciais, voltado à defesa das terras indígenas e ao tratamento e prevenção de doenças, a cargo de uma equipe formada por membros da OPAN, do CIMI e da Prelazia de Lábrea. Missionários do JOCUM, uma organização aparentemente vinculada ao Summer Institute of Lingüistics, fizeram eventuais incursões aos Sorowaha, com o objetivo de estudar-lhes a língua (Suzuki, 1995). Os Sorowaha recebem ainda a atenção do psicólogo Mário Lúcio da Silva, que residiu entre eles durante vários anos.

5 Noblesse oblige, é preciso dizer que Darcy Ribeiro surpreendeu-se com os numerosos casos de suicídio entre os Urubu-Kaapor (Ribeiro, 1996: 493). E, em seu famoso ensaio sobre o líder dos Urubu-Kaapor que se lançou no rio Pindaré e foi devorado pelas piranhas, Ribeiro ([1957] 1976: 13-29) argumentou acerca da pertinência cultural desse ato auto-agressivo. Uma acentuada tendência suicida foi também constatada entre os Aguaruna, um dos grupos Jívaro no norte do Peru (Brown, 1984; 1986).

6 Entre as populações indígenas norte-americanas o tema do suicídio mereceu um destaque maior, uma vez que se percebeu a incidência em taxas bastante elevadas. Embora enfocado como um problema de saúde pública na maior 
parte dos estudos (ver Levcovitz, 1998, para um balanço dos resultados de tais estudos), existem vários trabalhos interessantes de cunho mais etnográfico (Voegelin, 1937; Fenton, 1941; Devereux, 1961).

7 Os Sorowaha falam uma língua da família Arawa, a qual congrega ainda os Jamamadi, os Kanamadi, os Jarauara, os Banawa-Yafi, os Deni, os Paumari e os Kulina (Rodrigues, 1986: 71-2). Todos os representantes dessa família lingüística habitam a região compreendida entre as bacias do rio Purus e do rio Juruá, dois grandes afluentes da margem direita do Solimões. Para informações mais gerais sobre os Sorowaha, ver Kroemer, 1985; 1989; e 1994.

8 Os subgrupos nominados mais citados nas narrativas históricas sorowaha são: os Jokihidawa no igarapé Pretão, os Tabosorodawa no igarapé Watanaha (um afluente do Pretão), os Adamidawa no igarapé Pretinho, os Nakydanidawa no igarapé do Índio, os Sarakoadawa no igarapé Coxodoá, os Yjanamymady nas cabeceiras do igarapé São Luiz, os Sorowaha no rio Cuniuá, os Korobidawa em um afluente da margem esquerda do Cuniuá, os Masanidawa na foz do Riozinho, os Ydahidawa no igarapé Arigó (afluente do Riozinho) e os Zamadawa no alto Riozinho.

9 O que talvez não seja indício de um acento patrilinear, já que, estigmatizadas de todas as formas na infância, as crianças "sem pai" sequer são, em geral, arroladas entre os parentes consanguiíneos, afora sua própria mãe.

10 Em seguida às fases da primeira infância, a grade etária sorowaha está dividida em seis estágios básicos:

\begin{tabular}{|l|c|c|c|}
\hline \multicolumn{1}{|c|}{ Fase } & $\begin{array}{c}\text { idade } \\
\text { aproximada }\end{array}$ & homens & mulheres \\
\hline \multicolumn{1}{|c|}{2 a 7 anos } & 2 a 7 & hawini & hazamoni \\
\hline de 8 até sokwady/menarca & 8 a 13 & kahamy & zamosini \\
\hline até adolescência do filho & 14 a 28 & wasi & atona \\
\hline até nascimento do neto & 29 a 38 & wasi dogoawy & wasi dogoawy \\
\hline até adolescência do neto & 39 a 52 & dogoawy & dogoawy \\
\hline cabelos brancos & 53 em diante & hosa & hosa \\
\hline
\end{tabular}


11 Para uma comparação com as demais variantes amazônicas, caberia destacar três aspectos curiosos da terminologia sorowaha: 1) a transmissão por descendência da relação elder/young (jija [irmão ou irmã mais velhos]; xoro [irmão mais novo] e koro [irmã mais nova]), para designar os primos paralelos; 2) a existência de um par de termos para os filhos de irmãos de sexo oposto, de maneira a distinguir os sobrinhos cruzados de um homem (hoahady) dos sobrinhos cruzados de uma mulher (zahkyra), ou seja ZC (h. f.) ${ }^{1} \mathrm{BC}$ (m. f.); 3) o uso de um termo recíproco (koma) para as relações afins assimétricas (sogro, sogra/genro, nora).

12 Segundo Antônio Brand (1995), os Guarani consideram o suicídio como uma "doença" que, anteriormente, não provocava muitas vítimas. "O suicídio vem, segundo os Guarani, porque a pessoa não consegue mais falar e este é o sinal da doença." O índice crescente expressaria, então, para o autor, um fenômeno contemporâneo. Entretanto, a antropóloga Edir P. de Barros (informação pessoal) alertou-me para o fato de que, em meados da década de 70, quando ali trabalhou, haviam sido notificados vários casos. E Darcy Ribeiro (1996: 454), em seus Diários Índios, fez menção aos jovens Apapokuva-Guarani que, ainda em fins da década de 40, já se suicidavam às centenas. De acordo com Brand, atualmente os maiores índices ocorrem nas reservas indígenas que foram demarcadas entre 1915 e 1928, em razão de problemas relativos à superpopulação, à sobreposição de aldeias e chefias, à dispersão da mão de obra em usinas e fazendas e à fome.

13 "É então natural que, em uma sociedade onde os contatos entre os homens se multiplicam, as ocasiões de suicídio sejam mais freqüentes. Mas isto não impede que as diversas espécies de motivos que possuem os homens para se matar se distribuam segundo as mesmas proporções nestes dois tipos de sociedade. Pode haver ali, para um mesmo número de homens, dois ou três vezes mais infortúnios na cidade do que no campo, ainda que essas ocasiões de suicídio sejam totalmente outras, aqui e lá, embora sob a mesma relação" (Halbwachs, 1930: 507).

14 A população média de 123,6 foi obtida a partir de um cálculo ponderado dos valores anuais, distribuídos numa curva demográfica irregular cujo ponto inicial é 109 pessoas em 1980 e o ponto final, 144 pessoas em fins de 1995. 
15 No levantamento genealógico que equipe do Projeto Zuruaha, Mário Lúcio da Silva e eu realizamos, as idades foram estimadas, para o período anterior a 1980, a partir de comparações com pessoas conhecidas.

16 Entre os Aguaruna, nos quais também os jovens suicidas são em maior número que os adultos, o fenômeno é predominantemente feminino, na proporção de duas a três mulheres para cada homem (Brown, 1986: 313).

17 As mocinhas, ansiosas para encontrar um companheiro e assim conquistar uma maior independência que a vida de casada descortina. Os rapazes, postergando qualquer compromisso definitivo, satisfeitos com as benesses da juventude e da masculinidade, envaidecidos, irrequietos e destemidos. Uma situação parecida foi descrita por Firth (1998), para os Tikopia.

18 Há vários indícios de que o olhar, um dos sentidos mais marcados nessa cultura, é sempre um gesto perigoso (doenças, morte etc.). Cf. Fank \& Porta, 1996 a: 38.

19 Os sentimentos que engolfam o suicida sorowaha não seriam muito diferentes do estado de inharõ que sucede entre os Urubu-Kaapor - raiva, cólera, revolta, crise emocional. O indivíduo se põe a destruir o que encontra pela frente e é abandonado temporariamente pelos companheiros. No caso do capitão Uirá, seu filho havia morrido durante uma epidemia de gripe. Por este motivo, ele entregou-se à vingança guerreira, depois, com a família, lançou-se ao encontro de Maíra e, afinal, atirou-se às piranhas no rio Pindaré (Ribeiro, [1957] 1976: 13-29). Segundo Ribeiro, porém, a perfuração da artéria do pescoço com uma flecha era a maneira típica dos Urubu-Kaapor suicidaremse, quando "os sofrimentos físicos (...) ou morais (...) sobrepujam o limite que julgam suportável” (id., 1996: 493).

20 Informação pessoal de Mário L. da Silva, 1997.

21 As razões que movem os suicidas Aguaruna espelham circunstâncias bastante análogas. Na interpretação de Brown (1986), trata-se ali de uma estratégia de contra-poder pelo qual mulheres pretendem privar o cônjuge dos seus serviços e rapazes desafortunados, inculpar antagonistas poderosos. 
Revista de Antropologia, São Paulo, USP, 2000, v. 43 nº 1.

22 Na verdade, os trovões de menor intensidade são ruídos de canoas que se chocam no patamar celeste, no momento em que as almas passam.

23 Em mais de um caso de suicídio de viúvas, bastou-lhes tão-somente sonhar uma noite com o marido falecido.

24 Estou chamando de feitiçaria um dos aspectos do xamanismo, a sua face malévola que responde pela causação de doenças e morte. Tal conotação parece-me adequada ao contexto etnográfico dos Arawa, já que estes não diferenciam entre feiticeiros, pajés ou xamãs. Sobre esta questão entre os Kulina, ver Viveiros de Castro, 1978: 82.

25 Ao destacar a relevância da função xamânica para a compreensão desse panorama sociológico, não estou afirmando a inexistência de quaisquer outros mecanismos sociais que articulem as unidades locais entre si; as trocas matrimoniais, as atividades rituais, o comércio, as disputas internas e as guerras, como já disse Marcio Silva para os Waimiri-Atroari, "contribuem, cada um a seu modo, para o estabelecimento das redes de relações entre grupos locais, ao mesmo tempo em que definem as suas configurações no tempo e no espaço" (1993: 176-7).

26 A analogia entre os Sorowaha e os peixes, motivo de um diálogo que Axa, homem de meia idade, um dos poucos com aptidões xamânicas, manteve com um espírito korime, repousa tanto na impotência dos humanos e da fauna ictiológica diante do konaha quanto na metamorfose póstuma da alma dos suicidas (Fank \& Porta, 1996 b: 181-7).

27 As mulheres são, em geral, incriminadas pelo suicídio do marido. Conforme Ohozyi, comentando a sequêencia de suicídios em 1992: quando um homem sorowaha morre, os demais homens ficam com raiva das mulheres (todas as mulheres, hadimedi) e apontam contra elas suas flechas, aleatoriamente, ameaçando matá-las. Somi suicidou-se (devido a uma faca que sumiu), e sua esposa Dixinomy foi considerada responsável pelo fato (o casal vivia então mais uma crise conjugal). Koakoy primeiro tentou tomar konaha na roça de Jadabo, mas Ohozyi espreitava-o e agarrou a raiz, impedindo-o de ingerir o sumo. Koakoy jogou o timbó fora e voltou para casa. Mas ainda zangado, atirou uma flecha (sem veneno) contra Dixinomy. A flecha atingiu a viúva Oxkewa, fora da casa. Mário (psicólogo) tentava socorrer Obonio, 
mas as pessoas acreditavam que já estava morto e não ajudavam. Mário insistia. Hamy (que também quis tomar konaha, mas não lhe permitiram) pegou suas flechas ameaçadoramente, mas Hynijyi conteve-o. Perguntei a Ohozyi em quem Hamy iria atirar. Sua resposta: "Hadimedi. Tomyry" - nas mulheres, em todas as mulheres! O contexto engendrado pelo suicídio, portanto, torna mais vívida a oposição entre os gêneros, ao modo de um confronto imediato que lança os homens contra as mulheres.

28 O impasse resulta, obviamente, da própria definição do fenômeno: "Chamamos suicídio todo caso de morte que resulta direta ou indiretamente de um ato positivo ou negativo, realizado pela própria vítima e que ela sabia que produziria esse resultado" (Durkheim, 1993: 5).

29 No ensaio sobre o "direito primitivo", Malinowski (1971) aplicou o modelo durkheimiano aos fatos trobriandeses, buscando assim nas relações entre o indivíduo e a sociedade as causas fundamentais do suicídio. Gesto sancionado pelo costume, cuja função seria o restabelecimento da "ordem e equilíbrio da tribo" (: 103), o suicídio trobriandês seguia condutas padronizadas - a vítima com adornos lançava-se de um coqueiro ou ingeria veneno; algumas vezes, já no alto, pronunciava um derradeiro discurso para a comunidade. A exposição pública de um comportamento desviante ou uma ofensa intolerável foram, nos casos examinados, a causa imediata da decisão individual. A relação incestuosa, a infração à exogamia clânica ou a prática de adultério, em si mesmas, não conduziam à decisão de tirar a própria vida, mas sim o escândalo posterior à sua denúncia por alguém que se julgava ofendido ou desprezado pela vítima (: 114-5). Para o suicida, o gesto representava tanto a expiação do crime ou pecado quanto um protesto contra os que revelaram publicamente o delito praticado. A explicação funcionalista, portanto, abordava o suicídio como resultado da pressão social exercida pela sociedade sobre o indivíduo, tendo como finalidade a coesão e o equilíbrio social.

30 Pode-se incluir nesse quadro, com toda a certeza, uma antiga instituição celta de ofertar a própria vida como contraprestação agonística, segundo os comentários de Mauss (1981) ao texto de Posidônio.

31 De acordo com Gabriel Cohn, tal preocupação não estava ausente do próprio pensamento durkheimiano, antes assinalaria precisamente a sua dimensão trágica: a "presença simultânea de um esquema analítico que opera com 
Revista de Antropologia, São Paulo, USP, 2000, v. 43 nº 1.

dualidades irredutíveis (o individual e o social, o sagrado e o profano e assim por diante) e uma concepção de fundo marcada pelo anseio à unidade íntegra, à plenitude da experiência e da consciência" (1997: 11).

32 Segundo a hipótese de Dumont, o individualismo moderno teria emanado de concepções muito semelhantes, marcadas pelo distanciamento do mundo e a conseqüente relativização da vida social - portanto, em "oposição à sociedade e como uma espécie de suplemento em relação a ela" (1985: 37-9).

33 Marcos Lanna (1996: 136, nota 4), ao criticar nos mesmos termos a analogia, sustentada por Seeger, Da Matta \& Viveiros de Castro, entre o renunciante indiano e os chefes e xamãs sul-americanos, sugeriu que, ao contrário de uma vertente individualizada, estes eram na verdade as "pessoas por excelência".

\title{
Bibliografia
}

\begin{abstract}
ADAMS, K. \& PRICE, D. (eds.)
1994

"Introduction”, South American Indian Studies, n. 4 (número especial

"The demography of small-scale societies: case studies from Lowland South America").
\end{abstract}

AZEVEDO, M. M.

1991 “O suicídio entre os Guarani Kaiowá”, Terra Indígena, vol. 58: 6-28.

BARROS, J.S'. A.

1930

Relatório da viagem de fiscalização ao rio Tapauá e seus afluentes, apresentado ao Inspetor do SPI no Amazonas e Acre, mimeo., fotos, 21 p., Museu do Índio/Sedoc, Filme 31, Planilha 380.

BARROS, M. B. A.

1991

"As mortes por suicídio no Brasil", in CASSORLA, R. M. S. (org.), Do suicídio: estudos brasileiros, Campinas, Papirus, pp. 41-59. 
BOHANNAN, P. (org.)

1960 African homicide and suicide, Princeton, Princeton University Press.

BOM MEIHY, J.C.S.

1994 "A morte como apelo para a vida: o suicídio Kaiowá", in SANTOS, R. V. \& COIMBRA, C. E. A. (orgs.), Saúde e povos indígenas, Rio de Janeiro, Fiocruz, pp. 243-51.

BONNEMÈRE, $\mathrm{P}$.

1992 "Suicide et homicide: deux modalités vindicatoires en NouvelleGuinée", Stanford French Review (International Journal of Interdisciplinary Research), vol. 16(1): 19-43.

BRAND, A.

1995 "Os suicídios entre os Guarani Kaiowá no Mato Grosso do Sul”, Porantim, set., vol. 178: 8-9.

BROWN, M. F.

1984 "La cara oscura del progreso: el suicidio entre los Aguaruna del Alto Mayo", in BROWN, Michael F. (org.), Relaciones interétnicas y adaptacion cultural: entre Shuar, Achuar, Aguaruna y Canelos Quichua, Quito, Abya-Yala, pp. 75-88.

1986 "Power, gender and the social meaning of Aguaruna suicide", Man, vol. 21(2):311-28.

CIMI-CONSELHO INDIGENISTA MISSIONÁRIO

1996 A violência contra os povos indígenas no Brasil: 1994-1995, Brasília.

COHN, G.

1997 "Durkheim: a busca da unidade num mundo dividido", Folha de S. Paulo, São Paulo, 16 nov. 1997. Mais, p. 10-11. 


\section{DEVEREUX,G.}

$1961 \quad$ Mohave ethnopsychiatry and suicide: the psychiatric knowledge and the psychic disturbances of an indian tribe, Bulletin 175, Washington, Smithsonian Institution, Bureau of American Ethnology.

\section{DUMONT, L.}

$1985 \quad O$ individualismo: uma perspectiva antropológica da ideologia moderna, Rio de Janeiro, Rocco.

\section{DURKHEIM,E.}

1977[1893] A divisão do trabalho social, vol. II, Lisboa, Presença/Martins Fontes.

1993[1897] Le suicide: étude de sociologie, Paris, Quadrige/PUF.

ELIAS, N.

1994 A sociedade dos indivíduos, Rio de Janeiro, Jorge Zahar.

FANK, J. \& PORTA, E.

1996 a A vida social e econômica dos Sorowaha, Cuiabá, OPAN/CIMI.

1996 b Mitos e histórias dos Sorowaha, Cuiabá, OPAN/CIMI.

1996c Vocabulário da língua Sorowaha, Cuiabá, OPAN/CIMI.

\section{FENTON, W.N.}

$1941 \quad$ Iroquois suicide: a study in the stability of a culture pattern, Bulletin 128, Anthropological Papers, 14, Washington, Smithsonian Institution, Bureau of American Ethnology.

FIRTH, R.

"Suicide and risk-taking" (1961), in Tikopia ritual and belief, Boston, Beacon Press, pp. 116-40. 
1998 Nós, os Tikopias: um estudo sociológico do parentesco na Polinésia primitiva, São Paulo, Edusp.

HALBWACHS, $\mathrm{M}$.

1930 Les causes du suicide, Paris, Félix Alcan.

JEFFREYS, M. D. W.

1952 "Samsonic suicide or suicide of revenge", African Studies, vol. 11(3): $118-22$.

KOOP, G. \& LINGENFELTER, S.

1980 The Dení of Western Brazil: a study of sociopolitical organization and community development, Dallas, SIL, Museum of Anthropology Publication, 7.

KROEMER, G.

1985 Cuxiuara, o Purus dos indígenas, São Paulo, Loyola.

1989 A caminho das malocas Zuruahá, São Paulo, Loyola.

1994 Kunahã Made, o povo do veneno: sociedade e cultura do Povo Zuruahá, Belém, Mensageiro.

LANNA, $\mathrm{M}$.

1996 "Reciprocidade e hierarquia", Revista de Antropologia, vol. 39(1): $111-44$.

\section{LEVCOVITZ, S.}

1998 Kandire: o paraíso terreal.O suicídio entre índios guaranis do Brasil, Rio de Janeiro, Espaço e Tempo/Te Corá. 


\section{LUKES, S.}

1977

"Bases para a interpretação de Durkheim", in COHN, Gabriel (org.) Sociologia: para ler os clássicos, Rio de Janeiro, Livros Técnicos e Científicos, pp. 15-46.

\section{MALINOWSKI, B.}

1971 Crimen y costumbre en la sociedad salvage (1926), Barcelona, Ariel.

MAUSS, M.

1974

"Uma categoria do espírito humano: a noção de pessoa, a noção do eu", in Sociologia e Antropologia, vol. I, São Paulo, EPU/EDUSP, pp. 207-41.

1981

"Sobre um texto de Posidônio. O suicídio, suprema contraprestação" (1925), in Ensaios de sociologia, São Paulo, Perspectiva, pp. 367-72.

MORIN,E.

1990

O homem e a morte, Portugal, Publicações Europa-América.

OVERING, J.

1988

"Styles of manhood: an Amazonian contrast in tranquility and violence", in HOWELL, S. \& WILLIS, R. (eds.), Societies at peace, Londres, Tavistock, pp. 79-99.

PINGUET, $M$.

1987 A morte voluntária no Japão, Rio de Janeiro, Rocco.

POLLOCK, D. K.

1985 Personhood and illness among the Culina of Western Brazil, Rochester, thesis, The University of Rochester. 
João Dal Poz. Crônica de Uma Morte Anunciada

1992 "Culina shamanism: gender, power, and knowledge", in LANGDON, J. M. (org.), Portals of power: shamanism in South America, Albuquerque, University of New Mexico Press, pp. 25-40.

1994 "Etnomedicina Kulina”, in SANTOS, R. V. \& COIMBRA, C. E. A. (orgs.), Saúde e povos indígenas, Rio de Janeiro, Fiocruz, pp. 143-59.

RANGEL, L.H. V.

1994 Os Jamamadi e as armadilhas do tempo histórico, São Paulo, tese, Pontifícia Universidade Católica.

REESING,E.

1991

"Xamanismo Kanamari”, in BUCHILLET, D. (org.), Medicinas tradicionais e medicina ocidental na Amazônia, Belém, MPEG/ CEJUP, pp. 89-109.

RIBEIRO,D.

1976

"Uirá vai ao encontro de Maíra: as experiências de um índio que saiu à procura de Deus" (1957), in Uirá sai à procura de Deus: ensaios de etnologia e indigenismo, Rio de Janeiro, Paz e Terra, pp. 13-29.

1996

Diários Índios: os Urubu-Kaapor, São Paulo, Companhia das Letras.

RIVIÈRE,P.

1984 Individual and society in Guiana, Cambridge, Cambridge University Press.

RODRIGUES, A.

1986

Línguas brasileiras: para o conhecimento das línguas indígenas, São Paulo, Loyola. 
Revista de Antropologia, São Paulo, USP, 2000, v. 43 nº 1.

SAHLINS, M.

1965 "On the sociology of primitive exchange", in BANTON, M. (org.), The relevance of models for social anthropology, Londres, Tavistock, pp. 139-236.

SEEGER, A., DA MATTA, R., VIVEIROS DE CASTRO, E.

1979 “A construção da pessoa nas sociedades indígenas brasileiras”, Boletim do Museu Nacional (Antropologia), s. n., vol. 32: 2-19.

SILVA, M. F.

1993

Romance de primos e primas: uma etnografia do parentesco waimiriatroari, Rio de Janeiro, tese, UFRJ/Museu Nacional.

SILVA, M. L. da

1994 a Um estudo sobre a sociedade suruwaha (versão provisória), mimeo., p. 12.

1994 b O drama de Xibiri-wiwi, mimeo., pp. 14.

SUZUKI, M.

1995 "Esboço preliminar da fonologia Suruwahá", in WETZELS, L. (org.), Estudos fonológicos das línguas indígenas brasileiras, Rio de Janeiro, Ed. UFRJ, pp. 341-78.

VIVEIROS DECASTRO,E.

1978 Os Kulina do alto Purus - Acre, Rio de Janeiro, mimeo., pp. 93.

VOEGELIN,E.W.

1937

"Suicide in Northeastern California", American Anthropologist, vol. 39: 445-56. 


\begin{abstract}
The practice of suicide through the ingestion of a fish poison juice (konaha) among the Sorowaha, a indigenous people that lives on the medium river Purus (AM, Brazil) and speaks an Arawa language, mediates closely the relations between the individuals and their society and projects a social totality by means of a individual ritual drama. The phenomenon relevance are evident not only by the mortality rates that the suicide causes - about a hundred times the western averages - but also by the unusual frequency that attempts happen there. The present essay examines the sociological variables of that death pattern and proposes another analytic dimensions.
\end{abstract}

KEY-WORDS: Sorowaha, Arawa, South-American ethnology, death, suicide, individual.

Recebido em maio de 1999. 